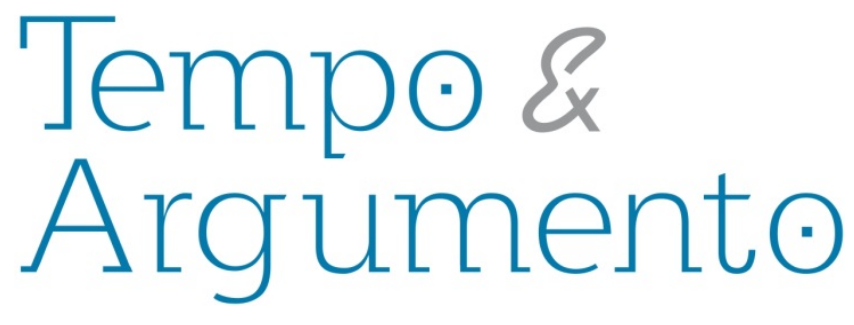

\title{
Getúlio Vargas: um estudo comparativo entre a revista ilustrada "Careta" e a imprensa comunista (1945-1954)
}

\begin{abstract}
Resumo
Utilizando como fontes a revista "Careta" e os periódicos da imprensa comunista, buscar-se-á fazer um estudo comparativo de como essas publicações desenharam a figura de Getúlio Vargas no período de 1945-54. Traços, conceitos de caricatura e charge, abordagens, público-alvo, busca do riso, da ironia e da denúncia serão abordados neste texto.
\end{abstract}

Palavras-chave: Getúlio Vargas; “Careta”; Imprensa Comunista; Caricatura; Charge.

\author{
Alberto Gawryszewski \\ Doutor em História Econômica pela \\ Universidade de São Paulo. Professor do \\ Programa de Pós-Graduação em Comunicação, \\ da Universidade Estadual de Londrina. \\ Brasil \\ agawry@sercomtel.com.br
}

\section{Para citar este artigo:}

GAWRYSZEWSKI, Alberto. Getúlio Vargas: um estudo comparativo entre a revista ilustrada "Careta" e a imprensa comunista (1945-1954). Revista Tempo e Argumento, Florianópolis, v. 9, n. 20, p. 186 - 229. jan./abr. 2017. 
Getúlio Vargas :a comparative study of the illustrated magazine " Careta" " and the communist press (1945-1954)

\begin{abstract}
Using as sources the magazine "Careta" and periodicals of the communist press, we will seek to make a comparative study of how these publications drew a picture of Getulio Vargas in the period of 19451954. Traits, cartoon and comedic strips concepts, approaches, target audience, the search for laughter, irony and delation will be addressed in this text.
\end{abstract}

Keywords: Getúlio Vargas; “Careta”; Press Communist; Caricature; Cartoon.

\section{Getúlio Vargas :un estudio comparativo de la revista ilustrada "Careta" y la prensa comunista (1945-1954)}

\begin{abstract}
Resumen
Utilizando como fuentes de la revista "Careta" y las revistas de la prensa comunista, buscan hacer acá un estudio comparativo de cómo estas publicaciones dibujaron la figura de Getulio Vargas en el período 1945-1954. Traces, conceptos de caricatura, enfoques, público objetivo, buscar la risa, la ironía y la denuncia se abordará en este texto.
\end{abstract}

Keywords: Getúlio Vargas; "Careta"; Prensa Comunista; Caricatura; Viñeta.

\section{Introdução}

Getúlio Vargas foi, provavelmente, um dos políticos brasileiros mais retratados em caricaturas e charges, não só pela sua figura "caricaturável”, mas principalmente por sua longevidade política (COSTA, 2011; FLORES, 2001; GARCIA, 2005; SILVA, 2014, entre outros).

Este trabalho visa fazer uma comparação entre traços, temas e abordagens de duas fontes diversas: a imprensa comunista brasileira (em especial as publicações editadas na cidade do Rio de Janeiro), com seus periódicos diários, semanários e mensais, direcionados às classes pobres, sindicalizados, intelectuais,na maior parte contrários ao político Vargas, e o periódico "Careta”, uma revista comercial, semanal, direcionada a um público variado, destacadamente de médio e alto poder aquisitivo, com um lado cômico importante e, também, crítica à figura de Vargas em todo o período estudado. Nos primeiros, encontramos cerca de 60 charges e caricaturas de Vargas e, no segundo, um número altíssimo, já que era uma revista eminentemente ilustrada e tinha em Getúlio Vargas um de seus objetos preferidos de retratar. 
Evidentemente, não poderíamos colocar neste trabalho todas as charges localizadas; assim, optamos por fazer uma seleção. No caso da imprensa comunista, procurou-se mostrar aquelas que sintetizassem as principais mensagens dos artistas e redatores do Partido Comunista do Brasil(PCB). Serão apresentadas por ordem cronológica e por tema. No caso da revista "Careta", procurou-se, igualmente, apresentar as principais linhas de construção da imagem de Vargas e como se desenvolveu com o tempo. Ao fim, discutir-se-á o conceito de charge e caricatura e buscar-se-á mostrar as semelhanças e diferenças pontuais entre as formas e as mensagens pretendidas e construídas nessas duas imprensas diversas.

\section{Um ligeiro histórico das fontes ora utilizadas}

A partir de 1945, na volta à legalidade, o PCB deu início à construção de uma vasta rede de publicações nacionais e regionais, revistas, romances, discursos, pensamentos, clássicos do marxismo (Lênin, Marx etc.), jornais e panfletos. Tal rede foi chamada de Imprensa Popular. A composição desta era ampla e buscava atingir diversos setores da população. Para os leitores comuns e setor de massas, a "Imprensa Popular" (antes

“Tribuna Popular”); para o simpatizante e militante, a "Voz Operária”; e para o militante, “A Classe Operária”. O primeiro, diário, com notícias da cidade, do mundo e do Partido. O segundo, semanário, com notícias sobre o movimento agrário, operário e sobre os partidos comunistas do Brasil e do mundo. Também existia o "Gazeta Sindical", editado na cidade do Rio de Janeiro pela Frente Sindical. Para os jovens, "Novos Rumos”, e para os intelectuais, as revistas culturais, como "Fundamento", "Seiva" e "Esfera".

O jornal diário "Tribuna Popular", editado na cidade do Rio de Janeiro, chegou às bancas em maio de 1945. Em seu primeiro número, na primeira página, encontra-se uma carta de Luiz Carlos Prestes, dirigente máximo do PCB: "O povo terá enfim o seu jornal, a tribuna popular que reclamava e de onde poderá expor suas reivindicações e debater os grandes problemas nacionais e que só ele pode de fato resolver". Nessa missiva, acompanhada pela sua foto, incluía outros escritos que tinham por mesmo objeto: "Saúdo [...] o advento em nossa terra de uma nova imprensa - a imprensa popular capaz 
de esclarecer, orientar e unir o nosso povo no caminho da democracia e do progresso”(“A saudação de Prestes", Tribuna Popular, 22/05/45, p.01). A referência aqui não é somente ao jornal, mas à imprensa popular, ou seja, uma nova rede de jornais que, ao contrário da então existente, seria um espaço para o povo propor e resolver os seus problemas. Mas a orientação correta seria dada pelo PCB.

No mesmo jornal acima citado, no seu editorial intitulado "O jornal que o povo espera", lemos outras frases que iam ao encontro dos dizeres de Prestes.

Nosso jornal chega na hora certa. Chega quando o povo necessita de uma tribuna a que possa assomar com a sua voz clara e firme, e através da qual receba mais diretamente a palavra orientadora de seus guias. Jornal que quer ser companheiro, amigo de todos, sem outro desejo que o de falar a verdade, esclarecer dúvidas, pôr fim a confusões, indicar o rumo seguro das aspirações comuns dos brasileiros [...]. ("O jornal que o povo esperava".Tribuna Popular, 22/05/45, p.03)

Se havia espaço para o povo expor suas ideias, debater, quem daria a palavra orientadora e definitiva seriam os guias. Como uma publicação de um partido que se intitulava seu representante, o sentido da "Tribuna Popular" era esclarecer as dúvidas do povo, pôr a cabo as confusões existentes nas mentes dos brasileiros, enfim, orientar, conforme as palavras de seus guias (Prestes - "guia de todos os brasileiros" - e Stálin "guia de todos os povos").

A revista "Careta", junto com a revista "O Cruzeiro", é uma das publicações mais usadas hoje como fonte de pesquisa, em especial iconográfica (uma busca simples na internet ajuda a visualizar tal afirmação). Muitas razões existem para isto, seja a facilidade de encontrá-la completa (em Bibliotecas no formato impresso ou em sites, no formato digital), seja pela sua longevidade (52 anos ininterruptos), e logicamente pela grande quantidade de imagens contidas (fotografias, charges, caricaturas e propagandas). Seu conteúdo atrai pesquisadores de diversas áreas de pesquisa.

"Careta" foi criada em 1908 na cidade do Rio de Janeiro, em um momento distinto de nossa história e da história da imprensa. A cidade carioca tinha passado por profundas transformações urbanísticas e arquitetônicas na perspectiva de mostrar ao mundo um 
novo Brasil, mais dinâmico e moderno. "Careta" fazia parte desse novo mundo, dividindo espaço com outras publicações ilustradas (em especial "Fon-Fon" e "O Malho") que surgiram nesse período. O desenvolvimento de novas técnicas de impressão, que possibilitavam a inclusão de imagens, até em cores, e grandes tiragens, levou ao barateamento do valor unitário das publicações e à capacidade de atingir um público inédito e variado, tanto local, como nacional e internacional. Além da grande tiragem possível, a expansão da propaganda - com uso de imagens e diversos formatos de fontes - ajudou na arrecadação monetária para as revistas, dando um caráter profissional e permanente aos seus colaboradores.

Fundada pelo empresário Jorge Schmidt, ex-diretor e fundadorde outras revistas ilustradas, “Careta”era um semanário (saía aos sábados), com cerca de 40 páginas, e tinha um caráter eminentemente comercial, como dito no próprio editorial de abertura: "Todavia, nossa esperança é justamente que o público morra pela Careta, a fim de que ela viva. E, feita cinicamente essa confissão egoísta [...]". Ainda conforme este: "[...] Careta é feita para o público, o grande e respeitável público, com P maiúsculo!" (Careta Ano I, nº 01, 06/06/1908, p.03).Este seria um público seleto, formador de opinião, intelectual e refinado. Mas não quer dizer que seu alvo também não fossea população mais humilde. As charges e caricaturas coloridas em sua capa, a qualidade gráfica, as colunas variadas (criadas no decorrer do tempo),repletas ou não de fotografias (de festas, bailes, esportes, solenidades, etc.), caricaturas, charges, charadas, tiradas de humor,etc. atraíam um público maior do que a elite financeira e intelectual, seja pelo acesso direto pela compra, seja pelo acesso indireto em locais públicos (barbearias, engraxates, etc.). Portanto, o alcance da revista "Careta" foi extraordinário para o período de sua existência. Deve-se dar destaque ao fato de que a maioria da população brasileira era analfabeta e, assim, as imagens possuíam um potencial de atração e, também, de uma interpretação diferenciada.

Se no início a proposta da "Careta" era unicamente fazer "caretas", isso foi mudado no decorrer do tempo, em especial a partir de 1930, quando a situação política a exigiu menos humorística. Na realidade, o debate político, econômico e social do país 
adquiriu um maior papel em seu conteúdo, incluindo o uso da charge e da caricatura nesse viés.

Em editorial de 1953, “Careta” escreveu: "[...]Fomosanti-revolucionários em 1930 como em 32; em 1935 como em 45 e sê-lo-emos hoje como amanhã. Do mesmo modo, somosanti-comunistas pelos mesmos motivos por que somos anti-fascistas e antinazistas, e porque somos anti-franquistas, anti-peronistas e anti-getulistas" (Careta, 01-041953, p.03).Assim, “Careta” nunca foi imparcial, promovendo debates sob sua óticasobre o que estava ocorrendo no país nas áreas econômica, social e, especialmente, política.

No período da ditadura de Getúlio Vargas ("Estado Novo", 1937-45), a imprensa foi duramente reprimida. Para o lançamento ou manutenção de uma publicação, era necessária a concordância do órgão regulador do Estado, em especial no período do Departamento de Imprensa e Propaganda (DIP). Assim, a partir de 1940, 420 jornais e 346 revistas foram interditados, fechados ou impossibilitados de existir (SILVA, 2014, p. 17).

Na órbita da criação da charge e da caricatura, o "Estado Novo" foi frustração; o sentimento reinante para os caricaturistas de humor no Brasil foi o da decadência de seu campo de produção, atribuída à violência da censura. A caricatura política deixou de existir para ceder lugar à caricatura de costumes (SGARBI, 1942, p. 27). Álvaro Cotrim (1965, p. 25), famoso caricaturista brasileiro, sobre o mesmo período disse:

A partir de 1937, com a implantação do celerado DIP, a caricatura, especialmente a política, que havia dado tão belos frutos, perdeu, naturalmente, seu ímpeto, [...]. Como na França de Luiz Felipe, em 1834, ao rigor da censura, os nossos caricaturistas também se voltariam, como seus ancestrais franceses, para a caricatura de costumes, um tanto anódino.

Lima (1963, p. 30) também reforça essa tese da liberdade de criação do caricaturista citando um de nossos maiores caricaturistas, J. Carlos:

Era assim que em pleno Estado Novo, falado à Revista da Semana, em agosto de 1944, o mesmo J. Carlos afirmava categoricamente a decadência vertiginosa da caricatura, entre nós, por falta de ambiente propício, porque 'reproduzir nos jornais, deformando-a, a cara de pessoas ilustres, famosas ou conhecidas por qualquer motivo não tem nenhuma significação. '[...]. 
Portanto, tanto o PCB, que se encontrava na ilegalidade, com seus principais líderes presos, como a imprensa, em geral, sofreram com a repressão e a censura no período estadonovista.

\section{Getúlio Vargas e a revista "Careta"}

Viu-se no item anterior que "Careta" foi atingida em cheio com a censura e com a frustração no criar. A figura de Getúlio Vargas, um personagem constantemente presente nas capas e páginas, tinha desaparecido (GARCIA, 2005, p. 140). Com a crise do regime ditatorial estadonovista e com a fragilização da censura, uma abertura ocorreu possibilitando uma reação da imprensa, em especial, no caso, de "Careta”.Esta, em maio de 1945, em sua capa, apresentava um desenho de um bolo de 15 anos. "Quinze anos, formosa idade! Tanta, tanta mocidade que chega tão cedo ao fim! Abandonada, esquecida, terás, encerrando a vida, a mesa vazia assim?" (Careta, 12/05/1945, capa "O Bolo".)Nesse mesmo número, a seção Loopingthe loop voltava a ser publicada, com o artigo "os semi-deuses", no qual relatavaa calamidade de uma nação que tivesse por líder alguém que se achasse insubstituível, um iluminado com atributos de semideus. Citava os exemplos de Alexandre, Cesar, Aníbal, Mussolini e Hitler.Ao pé do artigo informou que o mesmo havia sido censurado pelo DIP, em julho de 1942, com a alegação de que "em casa de enforcado não se fala de corda!". A partir dessa censura,a revista resolveu suprimir a coluna (Careta, 12/05/1945, p.03. Assinado pelo pseudônimo N.R).

Não só colunas voltaram a ser publicadas em 1945, mas a figura de Vargas também voltou a ser caricaturada e chargeada. Nesse sentido, uma campanha que desejava a realização de uma Constituintecom a manutenção de Getúlio no poder (Queremismo) foi amplamente contestada pela "Careta". Essa questão se somou à crítica anterior, segundo a qual o país não precisava de um "semi-deus".

Na charge 01, de junho de 1945, a revista denunciava a falsa mobilização popular em apoio à permanência de Getúlio Vargas no poder. O "QG", abreviaturageralmente associada a Quartel General, poderia ter na charge um sentido diverso,mas também 
poderia estar ligado ao movimento "Queremos Getúlio". No caso, procurou demonstrar que os cabos eleitorais estão no "QG" simplesmente pela"gaita" (dinheiro).

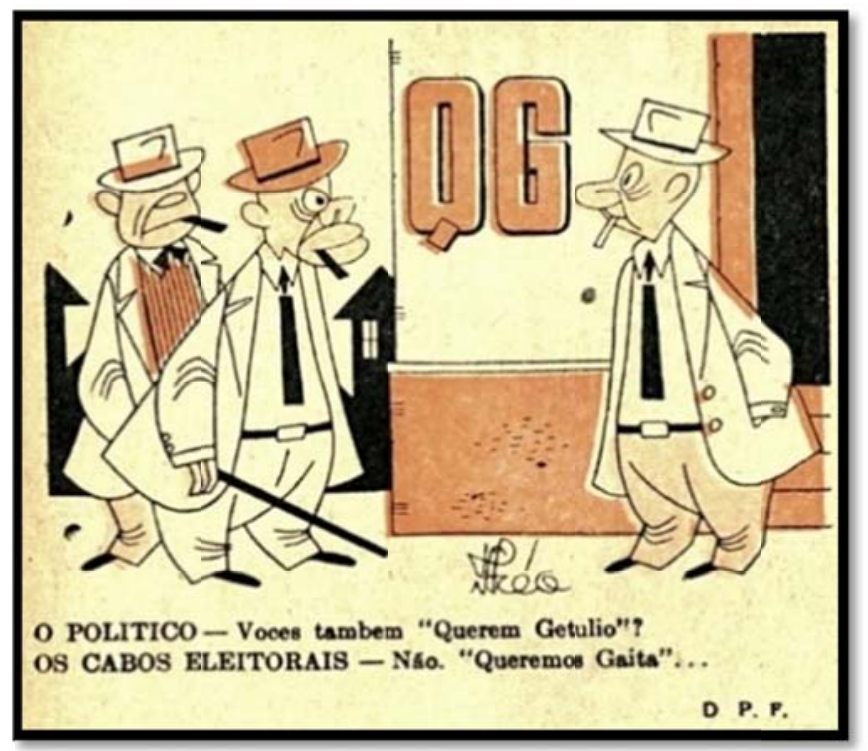

Charge 1, Careta, 23/06/1945, P.08

$\mathrm{Na}$ charge 02, de agosto de 1945, a crítica ainda é mais contundente na desmistificação do movimento queremista e na denúncia da situação da população no acesso aos itens básicos da vida (alimentação, habitação e salário). Getúlio Vargas, matreiro, faz uma leitura muito particular do movimento reivindicatório da população ao associá-lo ao do "queremos". Com o título sugestivo de "Os 'queremistas'...", demonstrava um Getúlio "cego" para os problemas da população.

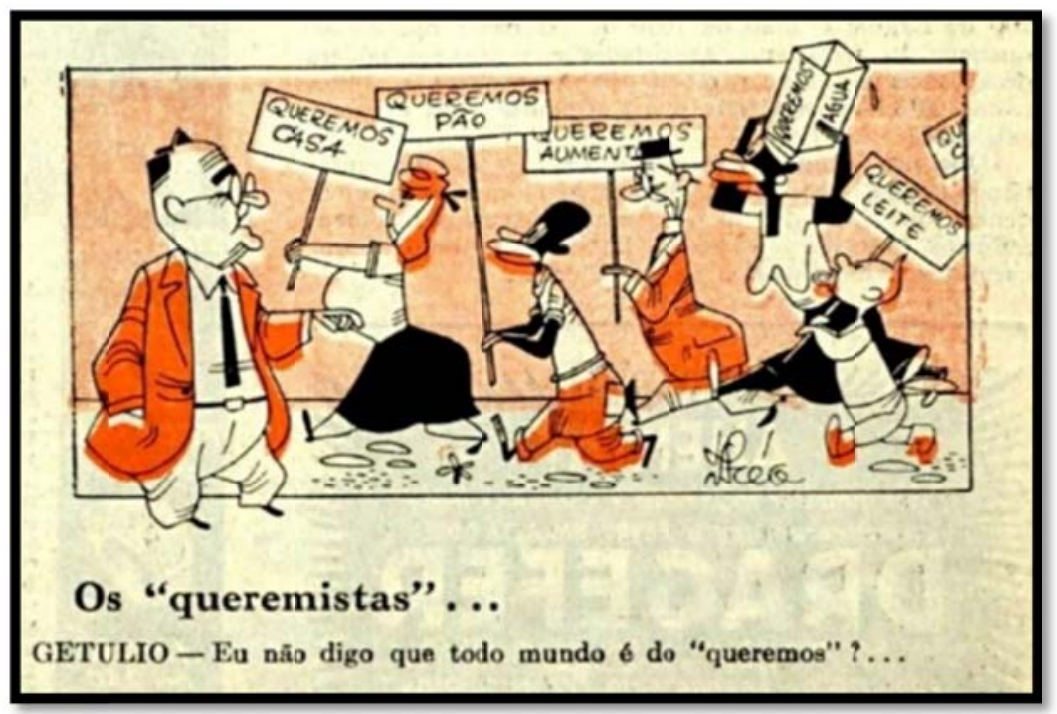

Charge 2, Careta, 11/08/1945 P.17 
Ainda dentro dessa problemática, a preocupação da revista “Careta”com a possibilidade da permanência de Getúlio no poder foi uma constante;assim foi em 1945, 1949, 1951. A charge 03, também de agosto de 45, sem a presença do ditador, uma criança sonha em ser presidente da república, e o pai responde que ela teria chance, já que era jovem e poderia esperar 30 anos.Na charge 04, de junho de 1951, ou seja, ainda nos primeiros meses do governo democrático de Vargas (1951-54), o governador de São Paulo, Ademar de Barros, comentou com Vargas que pensava em estudar propaganda eleitoral nos EUA para aplicar nas eleições de 1955, quando iriam escolher o substituto de Vargas. Este respondeu:"Onde é que vai haver eleições em 1955?". Fica clara a denúncia de um suposto desejo de continuísmo de Vargas no poder, em não respeitar a Constituição.



Charge 3, Careta, 25/08/1945. P. 17

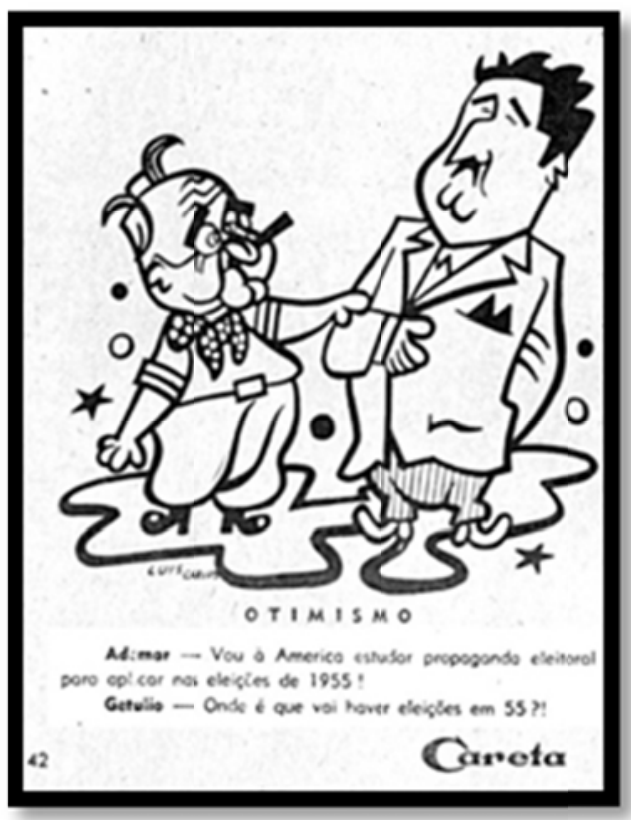

Charge 4, Careta, 16/06/1951, p. 42

Para as eleições de 1946, "Careta” apoiou abertamente o candidato Brigadeiro Eduardo Gomes ("O Brigadeiro é o Tal" -Careta, 10-11-45, p. 17; "Larga essa escada, pedreiro, Vem votar no brigadeiro" -Careta, 01-12-45, p. 17). Os editoraisi, desde maio de 1945, tratavam da economia e das questões sociais brasileiras ou das questões internacionais, como o fim da guerra. O editorial "Ele Disse", de agosto de 1954,tratou de "transcrever" o discurso de Vargas: "Atrapalhadores do Brasil [...]". Uma sátira do que seria o partido do ex-ditador, o Partido Atrapalhista Brasileiro. Trata-se de "uma 
organização criada com o objetivo de disputar cargos e vantagens para seus membros". Com tal ironia, procurou denunciar o caráter demagogo e reacionário de Vargas: "Aos pobres de espírito eu me dirijo para agradecer a grande manifestação de solidariedade ao sentimento que inspirou e dominou todo o meu governo" (Careta, 1408-1954.p.02).

Perdeu o Brigadeiro as eleições para a presidência em 1945 e, no ano seguinte,foi eleito Getúlio Vargas para o Senado Federal. Sua quase ausência no cargo foi motivo de críticas pela "Careta", em especial quando de sua eleição para presidência em 1950. A charge 05 parece que tem o propósito de lembrar aos eleitores o erro que tinham cometido em elegê-lo.Datada de novembro de 1950, veem-sedois personagens cômicos conversarem na rua. Um perguntou ao outro onde seria a posse de Getúlio, se seria no Senado. O outro não tinha certeza, mas disse que seria necessária uma pessoa avisar ao Getúlio Vargas onde ficava o Palácio Monroe. Ou seja, como seria possível um senador da república, após cinco anos legislando não saber onde ficava seu local de trabalho? Como pode uma pessoa receber salário e outros "extraordinários" por cinco anos sem trabalhar?

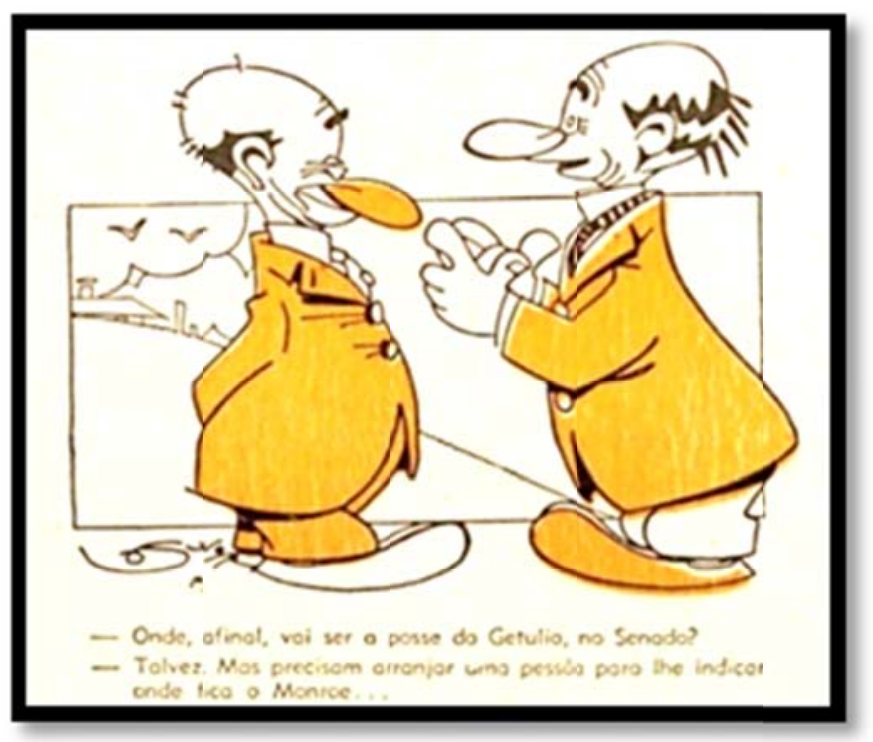

Charge 5, Careta, 11/11/1950. P. 08

Na mesma linha de crítica, uma capa de "Careta" (charge 016), do mês de setembro, logo após a homologação da vitória de Vargas pelo TSE, colocava em dúvida, 
frente ao seu histórico político, a capacidade de Vargas de cumprir a Constituição e não ameaçar a recente democracia brasileira, como já visto. Na charge, uma senhora perguntava ao condutor (cobrador Vargas) se o bonde passava pela rua da Constituição, ao que o mesmo respondeu: "Às vezes". Um bonde sem passageiros, indo para o bairro do Catete e tendo como motorneiroo presidente Dutra. Todos sorriem. Ao fim do bonde uma placa muito sugestiva do que poderia ocorrer nas eleições próximas: "Loucuras demaios de outubro."Em outra charge de capa (charge 07), de maio de 1951, Vargas estava selecionando o modelo a ser usado pela jovem constituição. O desenho apresentava a possibilidade da transformação da Constituição democrática de 46 na "polaca" de 1937. Getúlio perguntou ao Capanema: "Você acha que esse modelo de 1937 está fora de moda?".

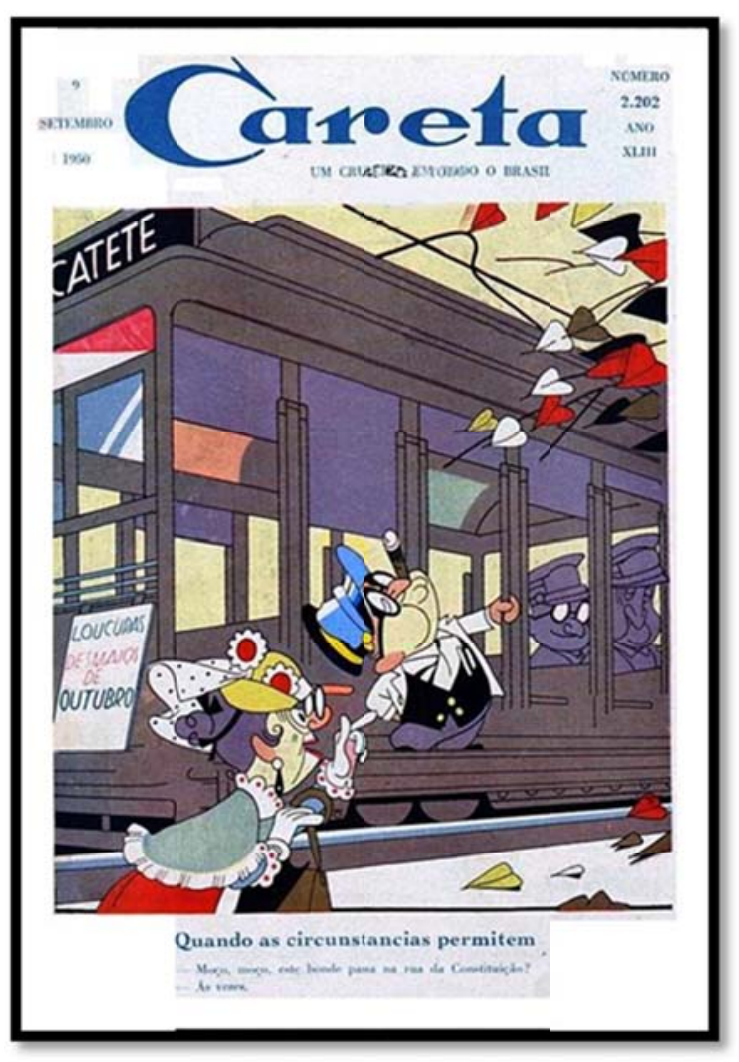

Charge 6, Careta, 09/09/1950

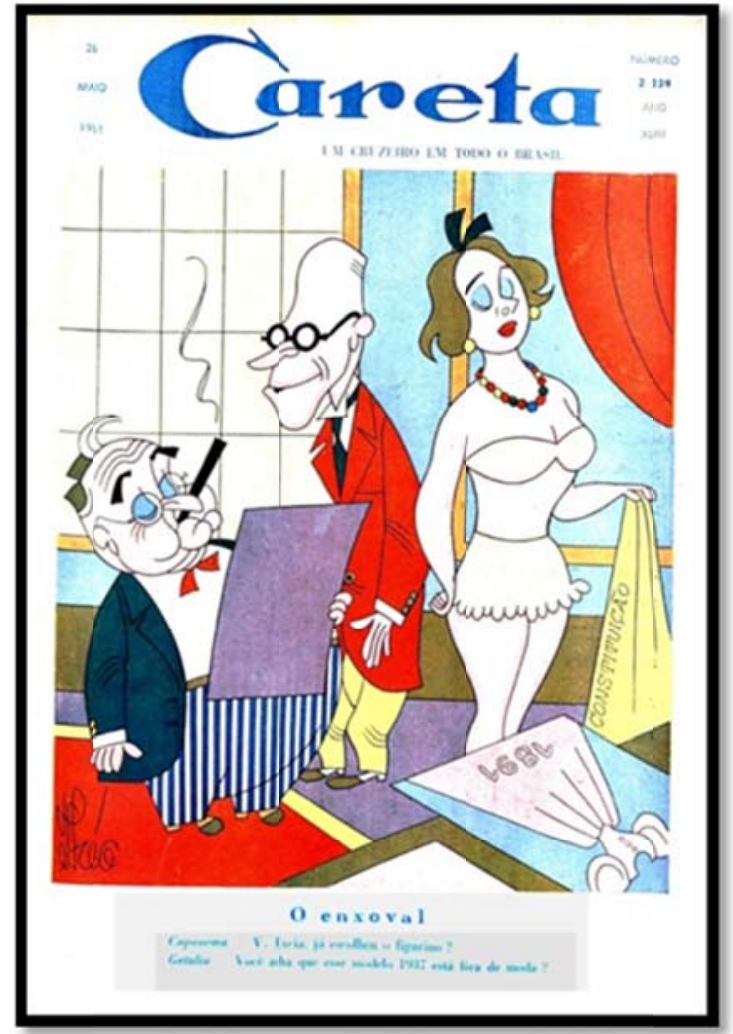

Charge 7, Careta, 26/05/1951

Mas afinal, quem seriam os eleitores de Vargas e por que votariam nele? Como publicação contrária ao Vargas, "Careta" tinha uma posição clara e pontual sobre essa questão. Em agosto de 1950, publicou a seguinte frase: "Haverá mesmo eleitorado neste 
país? Não acreditamos." (Careta,29-07-1950, p.38).Um mês antes da notícia anterior, a coluna Loopingthe loop, curiosamente, descreveu o eleitor de Vargas:

A popularidade que o ex-ditador goza nos meios prolletários promana exclusivamente deste fato; o sr. Getúlio Vargas transformou cada operário (feitas as exceções que todas as regras comportam) num malandro [...]. Estão convencidos de que, se isso acontecesse, passariam a trabalhar ainda menos e ganhar ainda mais.... (Careta, 08-06-1950,p.03.)

Assim, "Careta” navegava entre anão existênciade um eleitor (pelo menos em seu padrão) ou sua existência, mas um eleitor cooptado por motivos torpes. Por fim, curiosa a ausência da mulher eleitora na imagem.

Na série "Quem é seu candidato" (foram publicadas em número de cinco), há mais pistas sobre a visão da revista a respeitodo assunto. Cada tira possuía três quadros, mas para este texto serão escolhidos e juntados (montagem) apenas alguns.
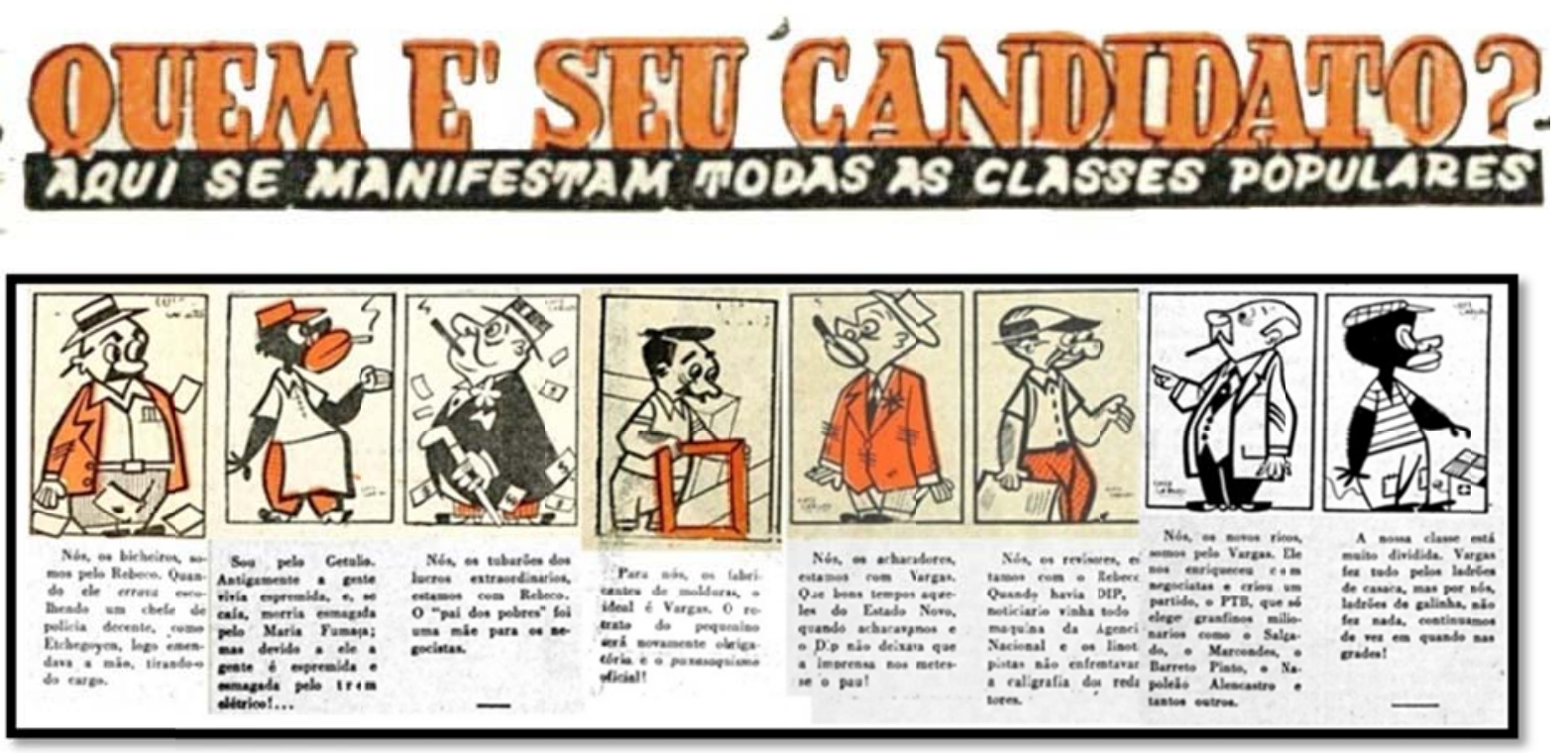

Charge 8, montagem do autor

Pelas caricaturas acima (ou quadrinhos), publicadas entre julho e agosto de 1950 (charge 08), assinadas por Luis Carlos (não foram obtidas maiores informações sobre este artista), temos exemplos de quem seriam os eleitores de Vargas: 
bicheiros,trabalhadores,tubarões dos lucros extraordinários1,fabricantes de molduras,achacadores do comércio,revisores dos jornais censurados, novos ricos e ladrões de galinhas (classe dividida). Por que votariam assim? As respostas seriam, respectivamente: Não seriam perseguidos pela polícia; por andarem espremidos nos elétricos e não mais em Marias Fumaças; o "pai dos pobres" foi a "mãe dos ricos"; pelo puxa-saquismo oficial; por não serem molestados e a imprensa impedida de se manifestar; pela censura do DIP, que facilitava seu serviço; pelas negociatas e pela fundação de um partido de grã-finos milionários (PTB, com Marcondes Filho, Napoleão Alencastro entre outros), e, finalmente, a classe dos ladrões de galinhas que estaria dividida por ainda ir para a cadeira, enquanto os ladrões de casaca continuavam soltos. $O$ desenho de cada quadro deixava claro como se representam. Assim, de maneira cômica, a "Careta" denunciou a atuação de Vargas no tempo do "Estado Novo", quando fez acordos com bicheiros, achacadores, ladrões de casaca, atravessadores do comércio e mesmo com alguns ladrões de galinha. Alertava para a censura à imprensa na época da ditadura estadonovista, inclusive denunciando ascondições de vida da população. Paralelo a isso tudo ainda houve espaço para a crítica aos puxa-sacos e ao uso da máquina estatal para o culto à personalidade.

E como votaram as demais classes populares?

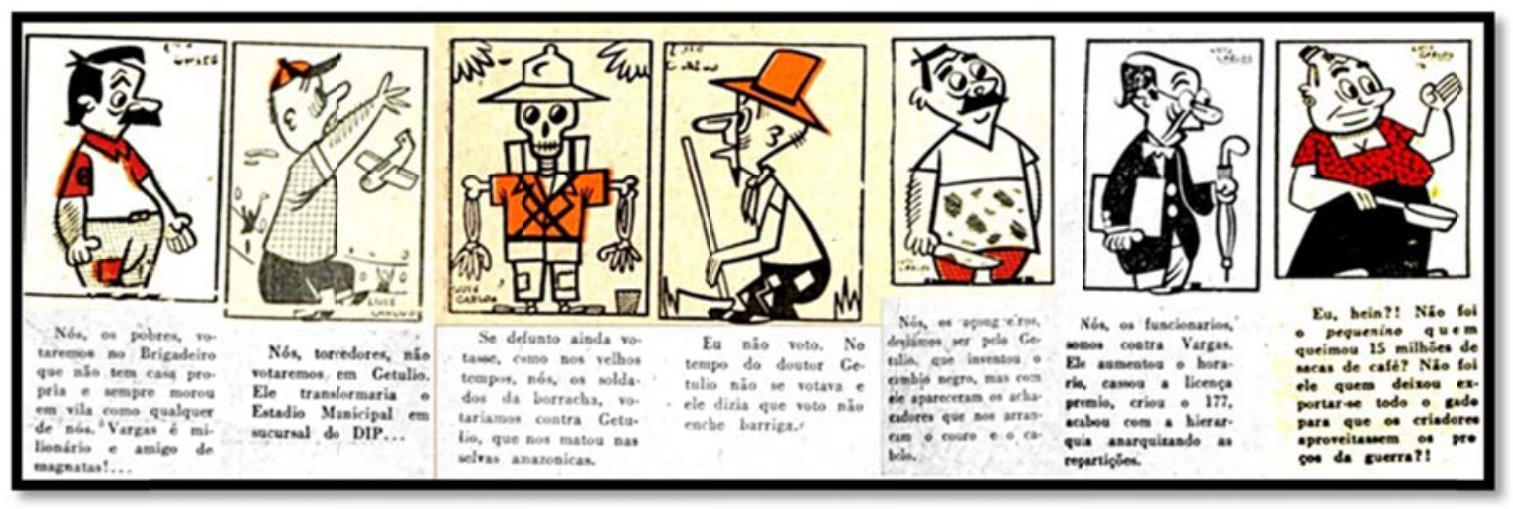

Charge 9, montagem do autor

1 Interessante é consultar o verbete no dicionário Aurélio. Verbete: tubarão - Bras. Fig. Industrial ou comerciante ganancioso, que se vale de quaisquer meios para aumentar os seus lucros, contribuindo para a elevação do custo de vida. 
Nos quadros acima (charge 09), chama a atenção a ausência de negros. No primeiro quadro, está escrito: "Nós, os pobres, votaremos no Brigadeiro que não tem casa própria e sempre morou em vila, como qualquer de nós. Vargas é milionário e amigo de magnatas!...". Quem mais não votava em Getúlio? Citam-se: os torcedores que não queriam o estádio municipal como sucursal do DIP; o soldado da borracha, que morreu nos seringais da Amazônia; a dona de casa que sofreu com a queima do café e a exportação de carne na época da guerra; o "Jeca" que relembrou uma frase de Vargas na época da ditadura:"voto não enche barriga"; os funcionários públicos, que tiveram o aumento na carga de trabalho, o fim da licença-prêmio e a anarquização da repartição e, por fim, o açougueiro, que ganhou com o câmbio negro, mas perdeu com os achacadores que com este vieram. Em síntese, apenas um voto era para o Brigadeiro que era uma pessoa comum, diferente do milionário Vargas; os demais apenas afirmaram que não votariam em Vargas pelas suas ações ou omissões. Noves fora, Getúlio Vargas receberia os votos dos homens das negociatas, desonestos, contraventores e do povo humilde que obteve melhorias ridículas (de trem movido por carvão para trem movido por energia elétrica).

“Careta”novamente apoiou, para as eleições de 1950, o Brigadeiro Eduardo Gomes por meio de charges (na capa e no seu interior), com editorais ("cidadão ínclito e patriota") e com frases soltas no pé da página. Da mesma forma, foi assim com os adversários do Brigadeiro: Getúlio seria "um politiqueiro matreiro e insincero" ou"Quem tiver saudade do mercado negro da gasolina não deixe de votar em Getúlio Vargas".

Com a eleição de Getúlio Vargas ou com mais uma derrota de seu candidato,restou à “Careta” a manutenção de uma posição crítica e a denúncia por meio da escrita e da imagem chargística do governo Vargas.Já foi vista a denúnciaà ideia de continuísmo de Vargas, incluindo o desrespeito à Constituição, mas vejamos outras no mesmo sentido. Com a manutenção da crise alimentícia, habitacional, de transporte e falta de água que vinha desde o "Estado Novo", "Careta” se posicionou na relembrança desse período e da falta de palavra de Vargas ao não cumprir promessas eleitorais. Nessa linha seguem as charges abaixo, publicadas bem no início do governo Vargas, em janeiro e abril de 1951. 


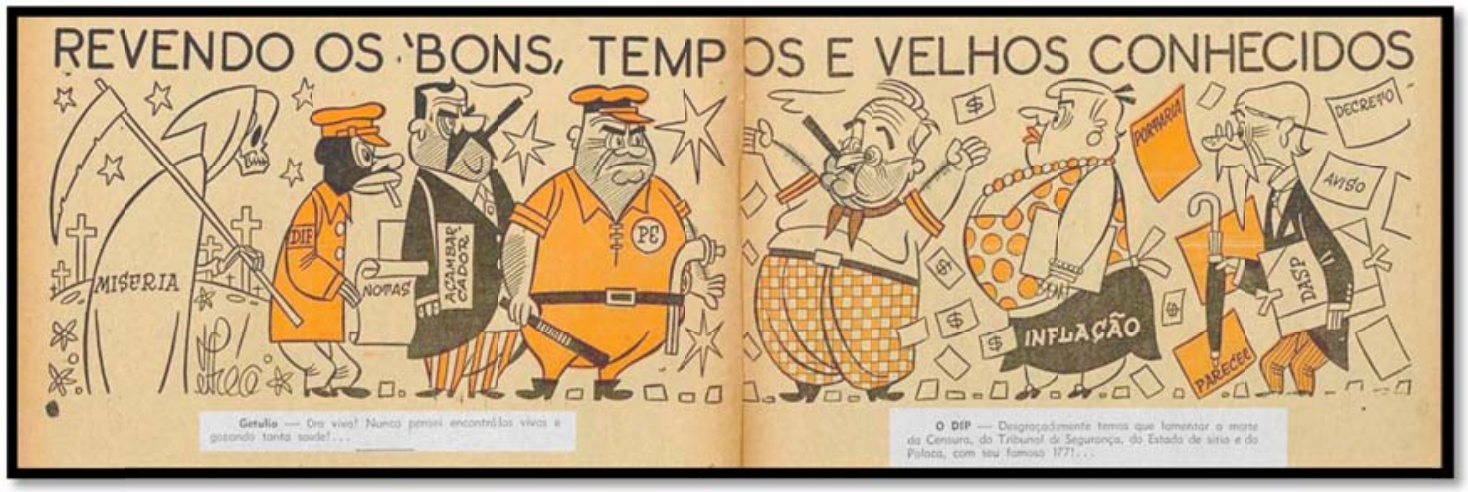

Charge 10, Careta, 13/01/1951. pp. 28/9

Na charge 10, intitulada "Revendo os bons,(sic) tempos e velhos conhecidos", “Careta” alertava para o perigo da volta, ou permanência, da miséria, inflação, do açambarcador (câmbio negro dos alimentos), da burocracia, da repressão, seja pela Polícia Especial (política), seja pela censura do antigo DIP. Todos devidamente identificados, o rico açambarcador, a elegante e obesa inflação, o velho Barnabé (DASP) com sua lentidão e burocracia, o corpulento agente da PE, o agente do DIP a visitar as redações da imprensa com as notas de censura e, por fim, a sinistra morte, devidamente paramentada. Getúlio, com os braços erguidos dando vivas aos velhos amigos: "Ora viva! Nunca pensei encontrá-los vivos e gozando tanta saúde!...". Então, o DIP advertiu Getúlio: "Desgraçadamente temos que lamentar a morte da Censura, do Tribunal de Segurança, do Estado de sítio e da Polaca, com seu famoso 177!...". Enfim, nem tudo eram flores para o presidente eleito, não poderia contar com a Constituição de 1937e nem com um tribunal de exceção. Mas como já foi visto, a Constituição poderia ser mudada, a palavra do exditador nada valia e suas promessas eram em vão.

A charge 11também possui um título, apresenta a fala de Vargas em dois momentos, um antes das eleições e outro depois. No primeiro diálogo, o "Getúlio (antes das eleições) - Eu conheço um meio de termos feijão barato, carne em abundância e casas para morar!". No segundo diálogo, o “Getúlio (depois da chuva de votos) - Se o Jeca plantar mais feijão, o feijão cairá de preço, se criar mais bois, teremos mais carnes e se o Waldemar colocar mais tijolos, teremos onde morar...". 


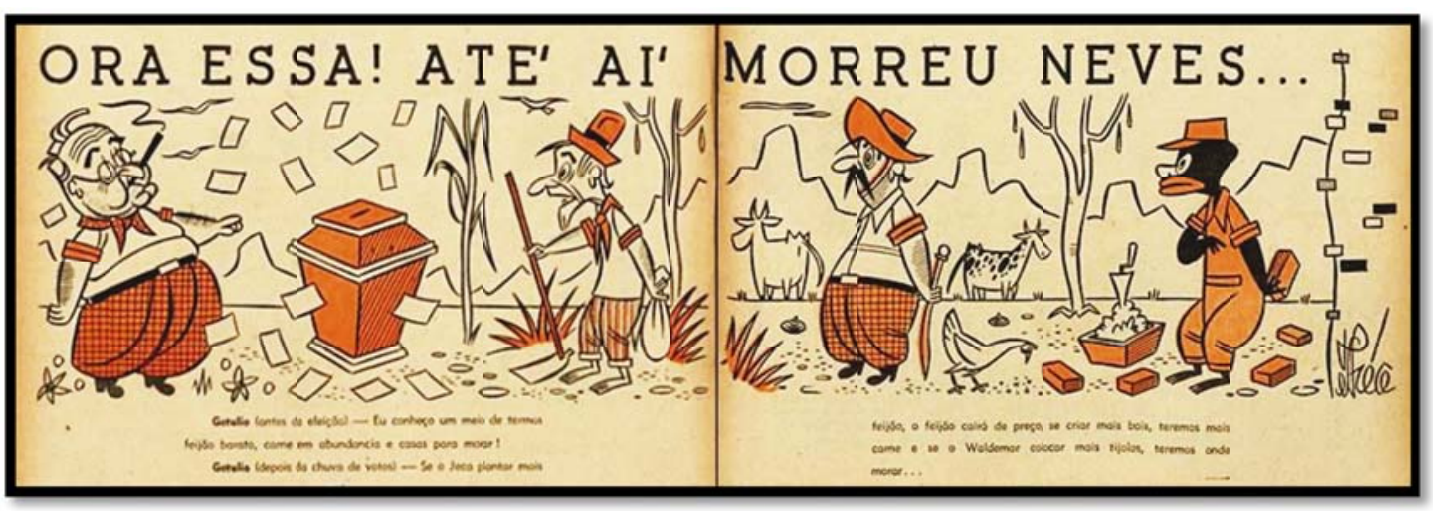

Charge 11, Careta, 03/03/1951. pp. 6/7

O chargista Théo apresenta uma urna sobre a qual "chovem" votos; um lavrador, um vaqueiro e um pedreiro, além, é claro, da figura de Vargas. Destoa o sorriso do presidente dos demais personagens. Jeca lavrador ficou de boca aberta, paralisado; Jeca vaqueiro, com ar desanimado, e o pedreiro Waldemar (outro Jeca) com ollhar de espanto. Mais uma vez a conta recaía sobre o povo. Assim, a culpa da falta de alimentos e moradia era pela baixa produtividade do trabalhador, nada relacionado com a falta de investimento em estrada, construção de silos, armazéns de estocagens, existência de atravessadores, do câmbio negro, do tabelamento dos preços, da falta de repressão do Estado, do excesso de emissão de moedas, do desvio de dinheiro público, da falta de remuneração adequada etc. A charge foi direto ao ponto da existência de um discurso demagogo de Vargas antes das eleições e uma falta de solução para depois das mesmas. Ou seja, projetava-se a manutenção dos problemas sociais e econômicos que existiam então.

Na mesma linha, encontra-se um personagem que apareceu quase todos os anos na capa de "Careta", Papai Noel. Este com suas cartas, estas pedindo pão, leite, carne... Na Charge 12, um exemplo que atingiu diretamente o presidente Getúlio Vargas. Na capa de 26 de dezembro de 1953, veem-se as figuras de Papai Noel e Vargas, cartas caindo sobre os dois, um título ("Fazendo confusão...") e um diálogo entre os personagens: “Papai Noel - Não sei por que, mas todos esperam que eu faça milagres!; Getúlio - Bem, mas você prometeu...; Papai Noel - Eu não prometi coisa alguma. Quem prometeu foi você...". Considerando a conjuntura econômica e social de crise que vivia o país e o 
momento festivo do Natal, essa charge atingia de maneira grave a figura do presidente Vargas. Destaca-se a palavra em negrito"prometeu". Um verbo comum nas bocas dos políticos brasileiros, que, em geral, não cumprem o tratado. Assim, essa imagem se casava com a descrição acima de Vargas, ao denominá-lo como "insincero".

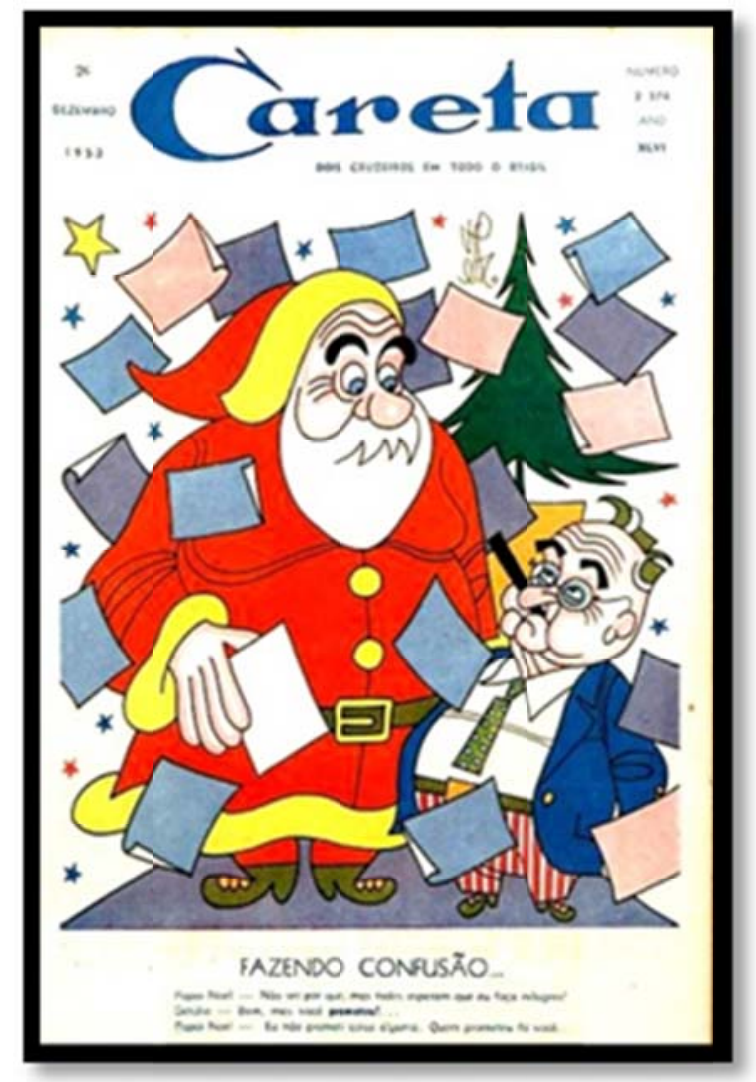

Charge 12, Careta, 26/12/1953

Se durante o período da Segunda Guerra (1937-45) a temática internacional era uma constante na capa e no interior de "Careta", a partir de 1946 e, em especial, de 1950, a mesma foi perdendo espaço. Como uma revista denominada deanticomunista, Stálin foi um personagem bem presente, inclusive em muitas capas no período 46-50. Mesmo a figura de Tio Sam não predominou na estudada publicação. O tema da guerra da Coréia, por exemplo, foi pouco explorado, quando se pôde encontrar, pelo menos, uma charge, a qual nos faz lembrar o período da aproximação do Brasil com os EUA nos anos 40, quando Vargas conquistou a siderúrgica de Volta Redonda como moeda de troca pelo apoio do Brasil aos Aliados. Na charge 13, de julho de 1951, Estillac Leal, Ministro da Guerra disse a Getúlio que não tinha soldados para enviar para a Coreia, ao que o presidente 
respondeu:"Mas, se você não manda soldados eles não mandam dinheiro!". Assim, para"Careta", o apoio ou não do governo aos americanos nada tinha com o ideário político-ideológico, mas apenas com a necessidade de dólares ao país. Curioso o título "Adeus 'divisas'", ou seja, ironiza tal forma de entrada de dólares (ou ao contrário) na economia brasileira.

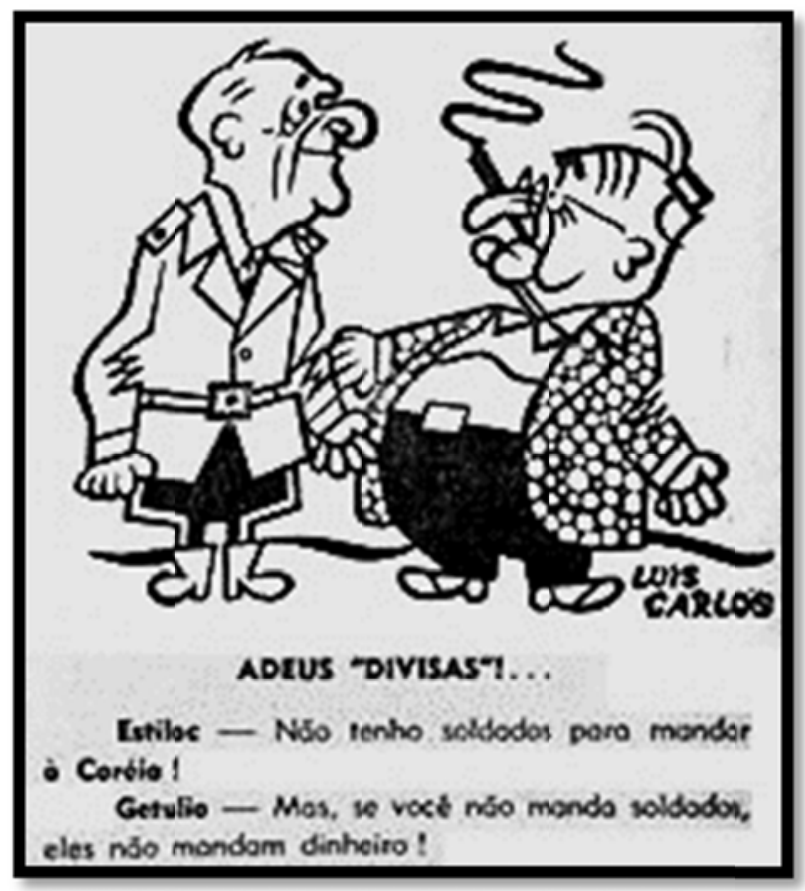

Charge 13, Careta, 12/06/1951. P.39

A crítica à política econômica de Vargas, como visto, foi uma constante em"Careta”, e igualmente à política econômica externa, conforme charge acima. Mas, em 1953, na capa, Théo contemplou os leitores da revista com a charge "El cuento" (charge 14). O conto do vigário? Para quem? O Ministro da Fazenda Oswaldo Aranha explicou para o Jeca que foi um grande golpe, já que tomaram 300 milhões dos americanos.O Jeca, de boca aberta e feliz, exclamou "Oba!" e perguntou para que seria aquele empréstimo, certamente imaginando investimentos para melhorar a sua vida. Para sua surpresa, o ministro respondeu: "Para pagar aos americanos!....". Portanto, nada de "cuento" e sim "cuenta". Mais uma vez,esta ficou para o Jeca pagar. 


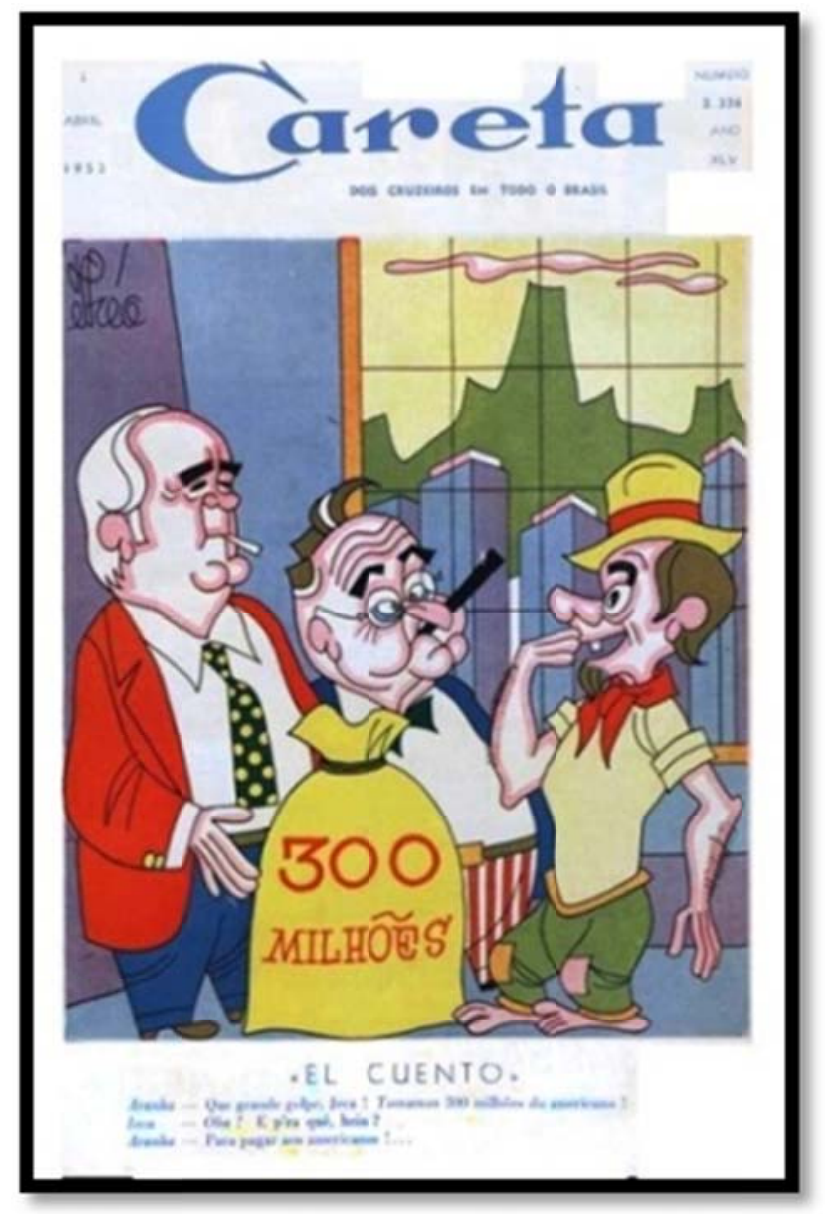

Charge 14, Careta, abril de 1953

Por fim, entre tantas opções, um tema palpitante na época estudada é a campanha do "Petróleo é nosso!". Pela linha editorial proposta de alinhamento ao combate a um Estado interventor na economia - visto que, para os editores de "Careta" os governos pós-30 tinham se caracterizado pelo empreguismo, falcatruas, imobilismo, incompetência administrativa -, mais uma estatal não seria bem vista. Já em 1948 advertia:

Já estava tardando que o Petróleo (escrevamos com maiúscula) se tornasse pedra de escândalo, como sucede com tudo que possa, neste país, interessar aos negocistas sem escrúpulos (...) O Governo, realmente, adquiriu refinarias, lançando mão de saldos congelados na França. Elas serão, porém, exploradas por felizardos consessionários, que pagarão juro módico ao governo, ficando com os lucros. (Careta, 30-1048, p.39) 


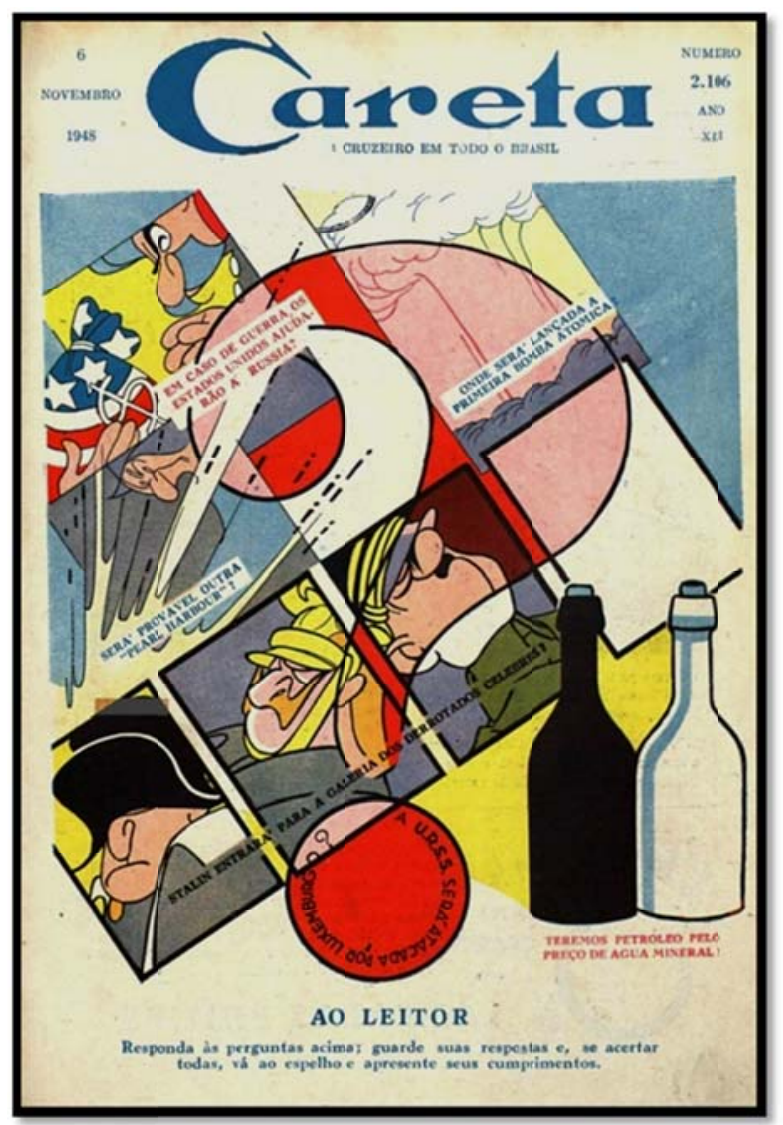

Charge 15, Careta, novembro de 1948

No mês seguinte ao escrito acima, em uma capa, J. Carlos misturou temas palpitantes para o momento, deixando ao leitor as possíveis respostas, com direito a cumprimentos. Entre perguntas sobre a bomba atômica, ataque da URSS por Luxemburgo, Stálin etc., há uma pertinente à questão presente: "Teremos petróleo pelo preço da água mineral?" A resposta? Bem, ela pode ser encontrada, por exemplo, na edição de fevereiro de 1953, ou seja, cinco anos depois, onde se pode ler:

Em um país em que meia garrafa de água Caxambú custa Cr\$3,00, é natural que tenhamos razões para recear que amanhã, com o 'monopólio estatal', sejamos forçados a pagar gasolina a $\mathrm{Cr} \$ 5,00 \mathrm{o}$ litro... Atentem para os preços da banana e confortemo-nos com o preço real $(\mathrm{Cr} \$ 0,80)$ de um litro de gasolina. E depois digam-nos se temos ou não razões de recear gasolina cara e ordinária, com o 'petróleo é nosso' .... (Careta, 1402-53, p.15)

Resumindo, "Careta”, no decorrer de 1948 a 1954, posicionou-se contrária (ou temerária) aomonopólio estatal do petróleo por considerar que as práticas do desvio de 
verbas, abrigo de parentes e políticos, incompetência na gestão da estatal não traria vantagens para o país, que tinha muito para investir em educação, saúde etc., e que não dispunha de verbas, pessoal qualificado e tecnologia para manter de forma lucrativa a Petrobrás.

Vejamos, no item a seguir, como Vargas foi visto pela imprensa comunista.

\section{Getúlio Vargas na imprensa comunista}

Em 1945, o ditador Getúlio Vargas anistiou os presos políticos do "Estado Novo" (1937-45). Era um novo momento político para o país. O Partido Comunista do Brasil (PCB) foi legalizado e Luiz Carlos Prestes, que havia passado 10 anos em cárcere, despontou como um dos políticos mais populares de então. Preocupado com as forças que considerava "reacionárias", desejando derrubar o poder constituído e visualizando um futuro mais "seguro" com uma constituinte com Getúlio, o PCB aderiu ao movimento que pedia a permanência do ditador até a confecção de uma nova Constituição ("Queremismo").

Vitorioso o golpe que destituiu Vargas, ao PCB restou seguir uma linha conciliatória denominada "ordem e tranquilidade", apostando em uma possível aliança entreburguesia e camadas proletárias. A luta era pela ocupação dos espaços democráticos existentes nas casas legislativas e nos cargos do Poder Executivo para realizar seus projetos políticos, econômicos e sociais, ou seja, as mudanças seriam executadas em plena democracia burguesa. Ocupar esses espaços exigia organização popular e combate nas esferas do debate político; lutava-se por votos pelo crescimento do PCB. Vargas, líder popular, surgiu como elemento a ser combatido, ou melhor, desmascarado por todos os tipos de linguagem (escrita, falada e visual).

Assim, Vargas somente apareceu na imprensa comunista carioca em janeiro de 1947, às vésperas das eleições para os Governos Estaduais e Municipais, Câmaras Federal, Estadual e Municipal, quando estava estruturando o Partido Trabalhista Brasileiro (PTB) e, em discurso, teria dito que "Ele" era a esperança dos humildes. À semelhança de Dutra, tinha sido poupado de ser caricaturado até então. 


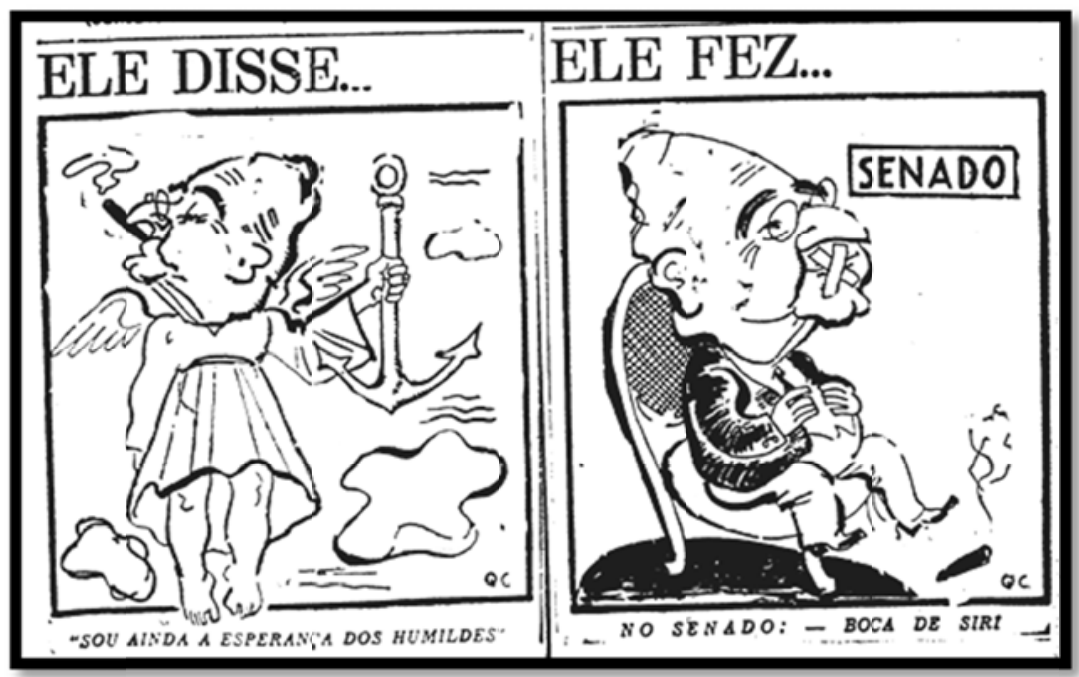

Charge 16, Tribuna Popular", 11/01/1947, p. 01.

As caricaturas que estão acima foram colocadas isoladas, ou seja, estavam na primeira página, mas cada uma em um canto. Uma notícia as separava. Na realidade, são caricaturas que unidas formam uma charge, ou seja, havia uma ruptura,mas, unidas, ajudavam a transmitir a mensagem desejada. De um lado, Vargas apareceu na forma de um anjo, com seu inseparável charuto, com uma âncora na mão esquerda (símbolo de segurança), afirmando que era ainda a única esperança dos humildes. De outro lado, vem o desmascaramento, no qual o ex-presidente, neste momento Senador da República, em nenhum momento teria feito qualquer declaração ou denúncia frente às necessidades da população brasileira (“boca de siri”), descansando calmamente em sua cadeira senatória.

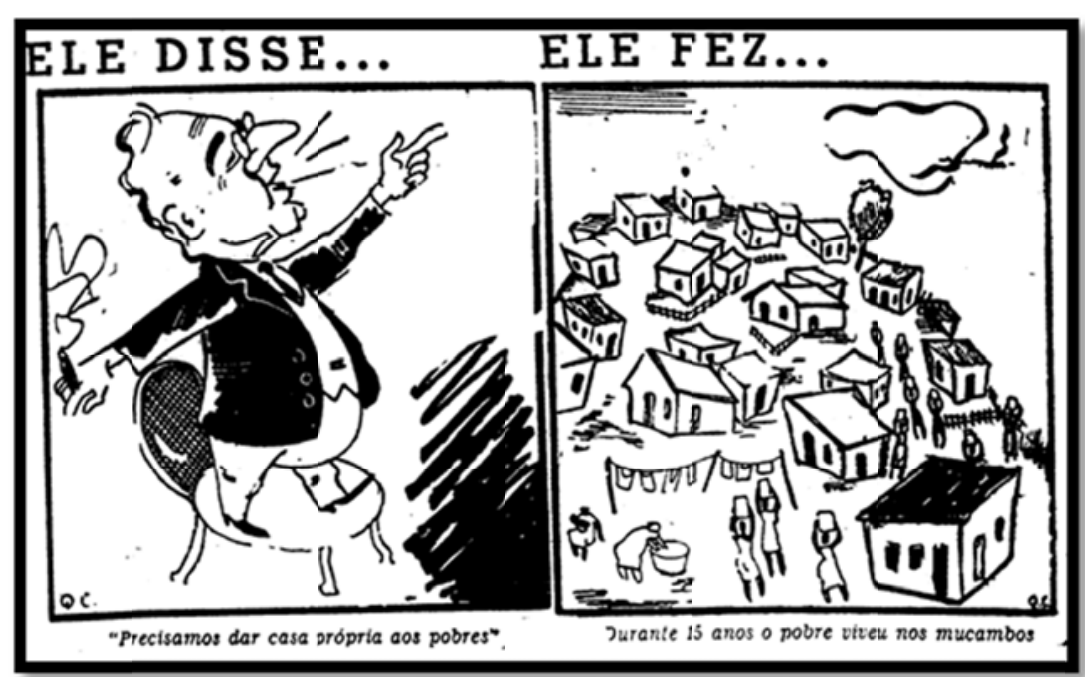

Charge 17, Tribuna Popular, 14/01/1947, p. 02. 
Em coluna do "Tribuna Popular", de 11 de janeiro de 1947, no mesmo dia das charges acima, duas páginas após, o editorialista escreveu sobre Vargas, considerando que sua estrela política estaria empalidecendo a olhos vistos, ou seja, era um político sem futuro. Não negou que em certo momento Vargas tenha marchado com o povo, como quando se colocou ao lado dos anseios deste, enviando a FEB para combater o fascismo. Entretanto, afirmou que não se podia deixar de lado o seu caráter autoritário, “demagógico golpista”:

Quando se lança numa campanha pelo fortalecimento de um falso Partido Trabalhista Brasileiro dos Marcondes Filho, dos Borghi, dos Pasqualini, dos Alencastro Guimarães e outros tubarões, ele visa, unicamente, a salvação dos interesses de sua classe, da classe dos fazendeiros reacionários, das negociatas, dos patrões imperialistas que mais servem aos seus interesses. ("O desmascaramento de Vargas nas eleições”,Tribuna Popular, 11/01/1947, p.03.)

Por fim, acusou-o de ser o principal responsável pela carestia, fome, salários baixos em que vivia a população brasileira, encobrindo suas responsabilidades com "chavões demagógicos".

O autor das charges foi o artista plástico e crítico de arte, Quirino Campofiorito, membro do $P C B$, que a partir deste momento fez uma série de tiras de "Ele disse...Ele Fez..." com o objetivo político de desmascarar, mostrar as contradições de Vargas entre seu discurso e sua prática como político e administrador. Quirino fez críticas diretas ao exditador, pelas condições de moradia, de alimentação e de saneamento básico em que deixou a população brasileira e, em especial, a carioca. Foram publicadas nos dias 12, 14, 15 e 16 de janeiro de 1947, às vezes na primeira página, às vezes não. Não vinham acompanhadas de qualquer texto, pois suas mensagens eram cristalinas: seus títulos, suas imagens e as legendas já davam conta ao receptor da ideia pretendida pelo autor. 


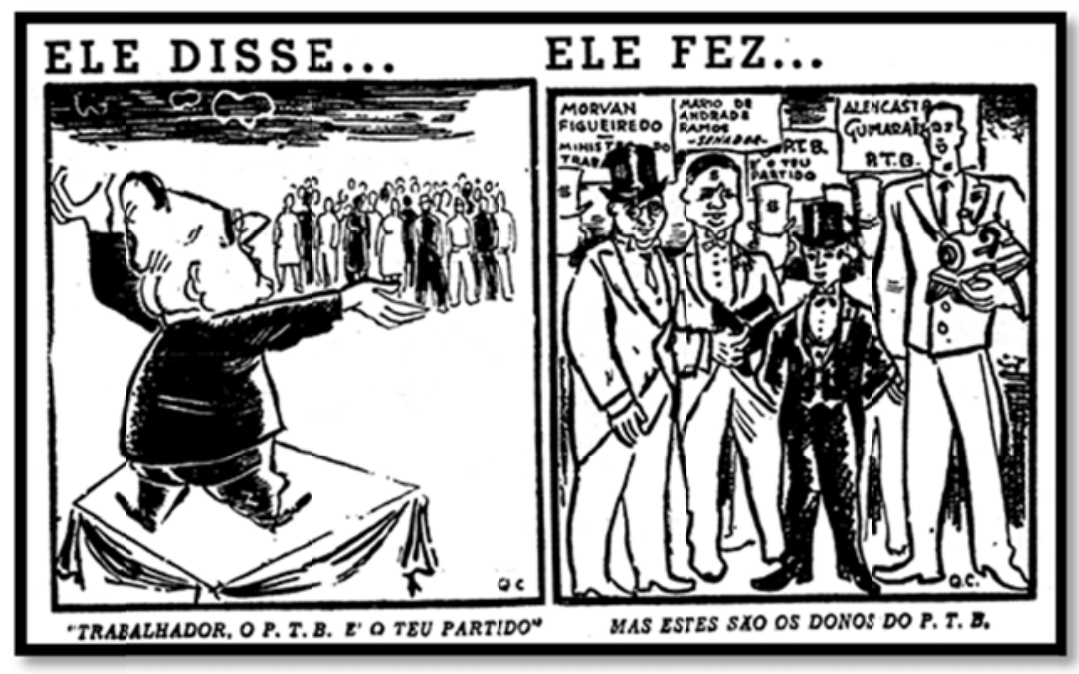

Charge 18, Tribuna Popular, 16/01/1947, p. 01

Como no editorial anteriormente apresentado, buscou desmoralizar Vargas e o seu partido, o PTB, associando-os à miséria e ao poder. Tinha um efeito detonador. $\mathrm{Na}$ charge 18 vemos Morvan Figueiredo, ex-ministro do Trabalho de Dutra, responsável pelas intervenções nos sindicatos, diretor da FIESP, Alencastro Guimarães, ex-ministro de Viação, e Mário de Andrade, candidato ao Senado pelo PTB, “testa de ferro da Light", todos ricos, quase todos utilizando o símbolo da riqueza, muito comum nas charges e caricaturas que criticavam os patrões e burgueses: a cartola. De outro lado, vemos Getúlio só, desvinculando sua imagem dos "ricos", afirmando de seu palanque aos ouvintes trabalhadores que o PTB era o partido deles. Mais uma vez buscou desnudar, desmascarar, destruir o discurso de Vargas e mostrar suas "falsas verdades", suas falas “mentirosas".

Após o ano de 1948, a imprensa comunista carioca sofreu constantes problemas com o governo Dutra, com empastelamentos (invasão e destruição das máquinas da redação e das oficinas gráficas) e dificuldades financeiras. Não nos foi possível localizar o jornal “Imprensa Popular", substituto do “Tribuna Popular”, proibido de circular pelo governo Dutra, no período 1949/50, o que certamente limitou um pouco nosso trabalho. Entretanto, ao consultarmos os jornais “Momento Feminino" e "Gazetta Sindical", no período de 1947/51, percebemos a escassez de imagens de Getúlio. Só retornou em abril de 1951 no diário "Imprensa Popular", justamente com o primeiro quadro da charge 18, 
ou seja, Getúlio Vargas no palanque, mas sem o título "Ele disse" e seu discurso, mas com a seguinte legenda: “- De promessas, o povo já está cheio-”. Já reconduzido por voto direto ao cargo de presidente da República, Vargas fez um discurso no programa "Hora do Brasil", onde analisou a crise econômica e social por qual passava o país. A reportagem, que era ilustrada pela charge, acusava o governo Vargas de nada fazer para conter a alta do custo de vida e por colocar nos postos-chave da administração os interessados na crise, os "tubarões”. Chamava-se a referida reportagem: "Responsável o governo pela miséria do povo" (“Responsável o governo pela miséria do povo”, Imprensa Popular, 10/04/1951, p. 01).

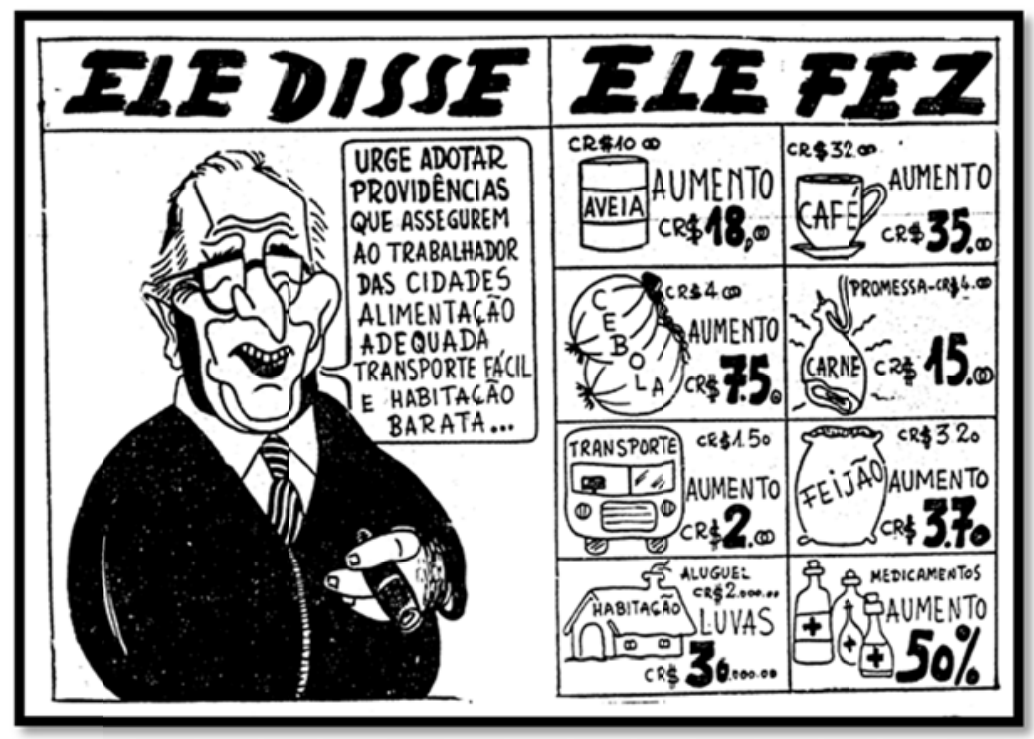

Charge 19, Imprensa Popular, 11/04/1951, p. 01

Logo após, foi publicada na primeira página a charge 19, demonstrando que, possivelmente, esta seria a regra: as denúncias contra o governo Vargas. O desenho retomou a ideia de Quirino e demonstrou de forma cristalina o aumento do custo de vida, vinculando-o à figura do presidente, sempre com um sorriso no rosto e com seu charuto. Logo abaixo vinha uma reportagem sobre a exportação de carne, isto é, ela não ilustrava nenhuma notícia, fazia parte de uma estratégia da redação do jornal.2 
No jornal "Voz Operária”, somente encontramos uma nova caricatura de Getúlio Vargas no mês de maio de 1951, ilustrando uma coluna intitulada "Força irreprimível”, na qualcriticava a tentativa do governo de passar a imagem de que o "Apelo pela Paz" era somente mais uma campanha comunista. Afirmou, ao concluir a reportagem, que a força desse movimento era irreprimível ("Responsável o governo pela miséria do povo", Imprensa Popular, 10/04/1951, p. 01).

A campanha pela Paz Mundial tomou uma boa parte das páginas da imprensa comunista carioca no período estudado. Engajados no "Movimento Nacional pela Proibição das Armas Atômicas", caricaturistas e chargistas de diversas nacionalidades ilustraram de forma contundente as páginas dos principais jornais comunistas do mundo e do Brasil. O Partido Comunista pretendeu traçar as linhas de uma política internacional, criar uma identidade coletiva nacional pró-paz mundial.



Charge 20, Voz Operária, 25/08/1951, p. 03

A charge 20, de autoria de Jorge Brandão, publicada no "Voz Operária" em 1951, seria um exemplo da forma de expressão visual da campanha.Nela é possível ver o 
presidente americano Truman, o Secretário de estado Acheson e o general MacArthur, ao lado de um saco com um cifrão marcado, observando o "enrosco" de Vargas, Góes Monteiro e João Neves. Na mão de um desses personagens (provavelmente Góes) encontra-se um papel amassado com os dizeres "envio de tropas para a Coréia", e pela boca de João Neves escorre uma longa baba. Um enorme abaixo-assinado feito por brasileiros procurava impedir que o governo brasileiro aderisse aos anseios norteamericanos. A mensagem é compreensível para o leitor, pois as figuras do governo são identificáveis e mostrou que somente com a união (abaixo-assinado) seria possível derrotar a política guerreira, identificada por meio da bomba, dos governos brasileiro e norte-americano. O saco de dinheiro com seu cifrão, tema constante das caricaturas e charges, simbolizava o suborno realizado ou empréstimos sempre disponíveis ao Brasil, caso apoiasse os interesses norte-americanos. Assim, ao lado da União Nacional, vemos a desmoralização de um governo corrupto e belicoso.

Um mês depois, em setembro de 1951, "Voz Operária" atacou o presidente Vargas com a charge 21 , denunciando-o como responsável pelo aumento dos preços e pelo rebaixamento dos salários dos operários. No pé da imagem,o seguinte texto:"A política 'trabalhista' de Getúlio: enquanto os trabalhadores lutam por aumento de salários, os tubarões são favorecidos com novos aumentos dos preços." A figura clássica de Vargas com seu charuto à boca, olhando para o leitor e com um sorriso no rosto, como que debochando. Puxando os salários para baixo (reduzindo-os), usa seu peso para conseguir. O trabalhador (com um macacão) tenta reverter a solução. Aparentemente Vargas está vencendo. Utilizando-se um uma linguagem visual simples, de fácil identificação e entendimento, não necessitava do texto para fazer-se compreender. Uma denúncia clara à política econômica e social empreendida pelo presidente. O texto apenas reforça a imagem relacionando Vargas aos interesses dos "tubarões" e contrários aos trabalhadores. 


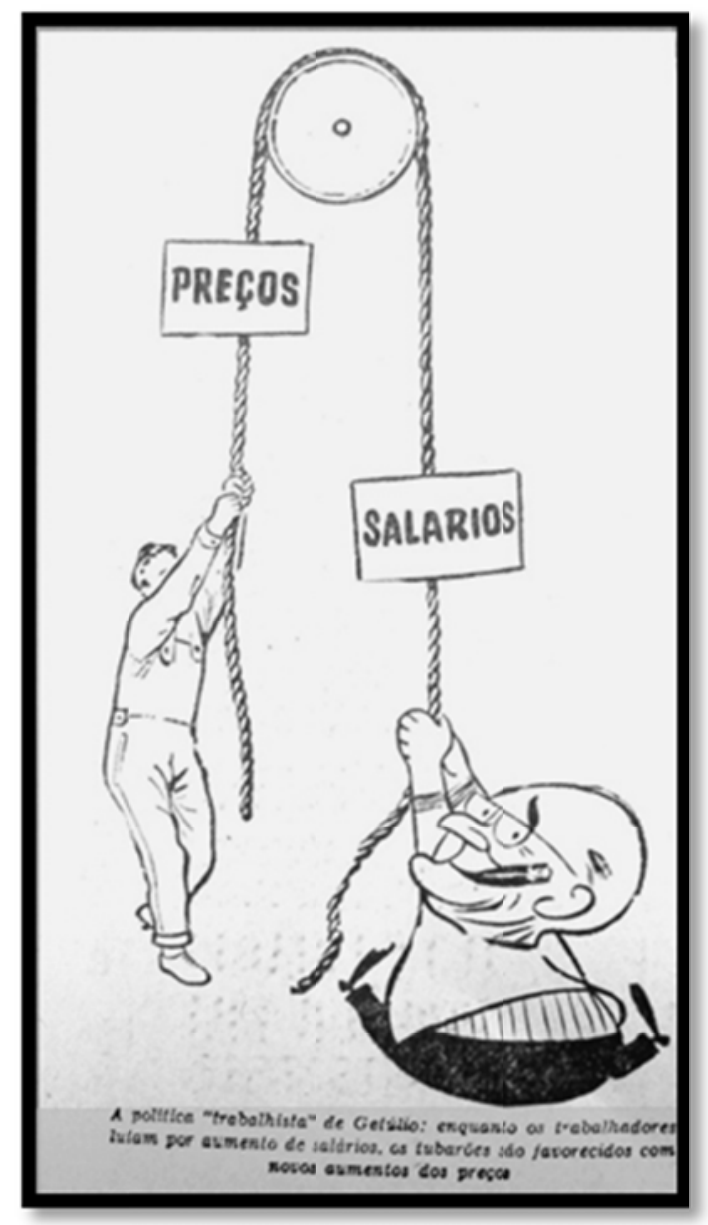

Charge 21, Voz Operária, 29/09/1951, p. 12

A charge 22, de autoria de DAN (não foram obtidas maiores informações sobre este chargista), publicada em "Fundamentos", uma revista voltada para assuntos culturais e pertencente à rede de publicações comunistas, ilustrava o artigo intitulado "O papel das condições sociais na gênese e evolução das doenças mentais", em quedissertava sobre o problema da saúde mental nos Estados Unidos e a redução da frequência de doenças mentais na União Soviética. Assim, percebe-se, ao olhar a imagem, que tal ilustração era totalmente fora de sentido. Ou melhor, em qualquer lugar ou publicação caberia denunciar Vargas. No caso em questão, temos três personagens do cotidiano do pobre brasileiro: a pobreza, a doença (vinculada às condições de moradia, trabalho e alimentação) e a falta de escolas. Vêm cobrar de Vargas o cumprimento da promessa de campanha. Veja-se que o chargista representou os problemas do povo sob três mantos, pois a morte, a carestia e o analfabetismo não queriam ser extintos. Quem 
queria seus fins era o povo, propriamente dito. Assim, Vargas, gorducho e com seu charuto (denominado de "desmemoriado") respondeu: "Não... Não me lembro que houvesse dito tal cousa."

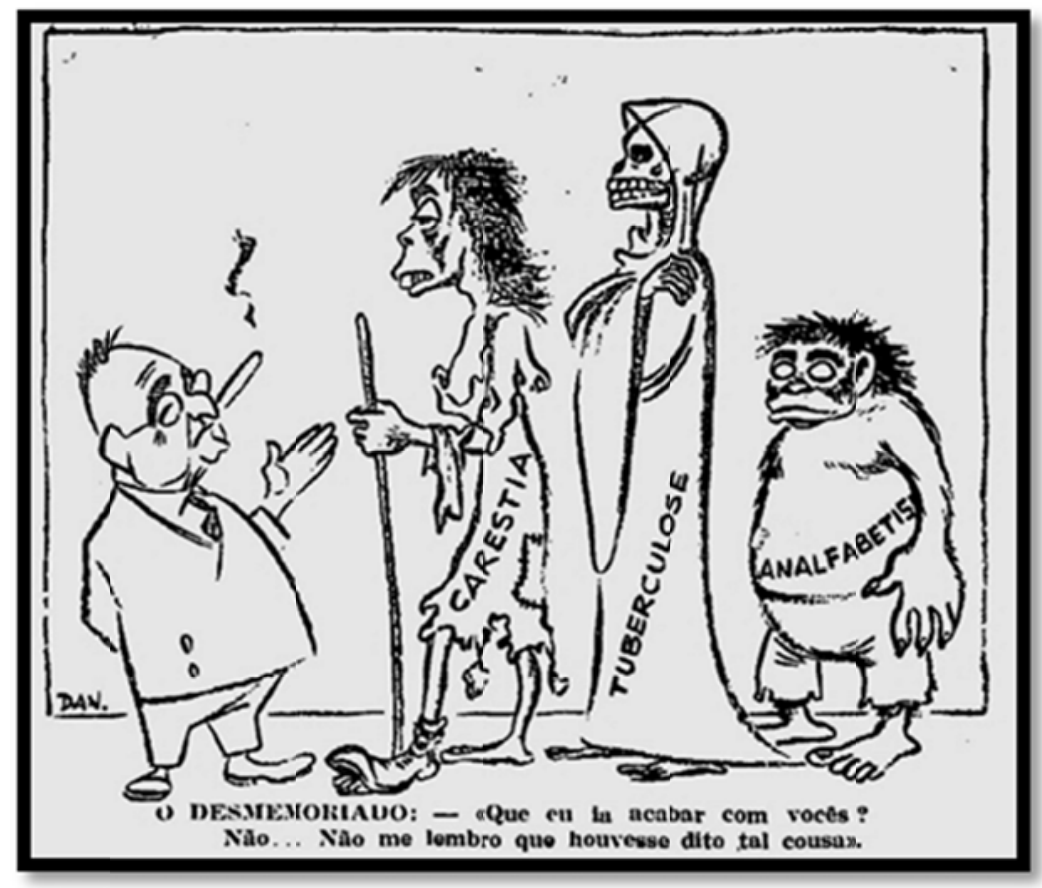

Charge 22, Fundamentos, março de 1951, p. 13.

Faz-se necessário, entretanto, voltarmos um pouco no tempo para localizarmos bem as posições assumidas pelo PCB perante o governo Vargas. Podemos dizer que uma mudança significativa ocorreu em relação ao governo e à burguesia nacional, uma vez que esta deixava de ser uma possível aliada, a partir de 1950. Em agostı, foi publicado pela imprensa comunista, um documento pelo Comitê Central, que passou a ser conhecido como o "Manifesto de Agosto de 1950". Segundo João Falcão, "este manifesto causou um grande impacto entre os militantes. Era de uma agressividade inaudita" (FALCÃO, 1988, p. 378).

Esse manifesto foi gestado dentro de uma situação internacional de acirramentoda "Guerra Fria". A ideia de uma frente democrática para o desenvolvimento industrial do país foi abandonada, o que gerou a defesa da nacionalização dos bancos e das empresas industriais e comerciais pelo Estado. O "Manifesto" pode ser sintetizado 
em oito pontos: 1) adoção de um governo democrático e popular; 2) luta pela paz e contra a guerra imperialista; 3) luta contra a submissão brasileira ao jugo imperialista; 4) terra para quem nela trabalhasse; 5) desenvolvimento independente da economia nacional; 6) liberdade para o povo brasileiro; 7) condições melhores de vida para as massas trabalhadoras; 8) instrução e cultura para o povo, e 9) criação de um exército popular de libertação nacional (CARONE, l982, pp.109-111).

Impedido de participar das eleições de 1950 para os cargos majoritários e para o legislativo, a situação do PCB ficou ainda mais delicada. Assim, foi nesse ano eleitoral que ocorreu o grande rompimento do discurso político do partido. O governo Dutra (19461950), que já era atacado, foi definido no chamado "Manifesto de Agosto" como "uma ditadura feudal-burguesa a serviço do imperialismo", que deveria ser substituída por um governo democrático popular. Propunha-se a criação de um exército de libertação nacional, sob sua direção para executar essa tarefa.

Posicionando-se pelo voto nulo nas eleições de 1950, o PCB se isolou mais ainda das massas, pois colocou no mesmo lado da moeda pessoas declaradamente nacionalistas, democráticas e de defesa dos interesses dos trabalhadores com outras de caráter nitidamente reacionário e antipopular. A vitória esmagadora de Vargas, demonstrando o fraco desempenho político do PCB, não mudou a postura deste, acusando também Vargas de "entreguista". Assim, as caricaturas e as charges foram armas poderosas da imprensa comunista carioca para construir uma visão sobre esse político. Ao lado das imagens, expressões como "vendilhão', “traidor”, “demagogo”, “agente do imperialismo" entre outras, tornaram-se constantes.

Um exemplo dessa visão é dado na notícia seguinte ("Chegou a Washington a quadrilha de João Neves", Imprensa Popular, 25/03/51, p. 01), publicada no jornal “Imprensa Popular", em quese relatava o envio para Washington, da comissão brasileira que participaria da Conferência de Chanceleres. O jornal chamou a comitiva de "quadrilha", seus membros de "os vende-pátria", pois estariam indo à capital americana para receber as ordens para a mobilização das forças latino-americanas para a guerra da Coreia.Acompanhando o texto, colocado na primeira página da edição, vemos a caricatura de três membros da comissão ou "quadrilha", com suas respectivas "relações": 
Schmidt, da Duperial, Santiago, autor do Código de investimentos e Bolças, da Coca-Cola. Por fim, no título da notícia e em seu interior, João Neves, "assalariado da Standard Oil", foi chamado de "lacaio", linguagem própria da época e do PCB, quando se dirigia aos seus inimigos políticos. Este político foi, juntamente com Vargas, o mais visado e caricaturado, em especial pelo cargo que exercia no governo, Ministro das Relações Exteriores (195153), no qualfoi defensor de um alinhamento completo com o EUA, inclusive com a remessa de soldados brasileiros para a guerra da Coreia, como bem afirmou a matéria do jornal.

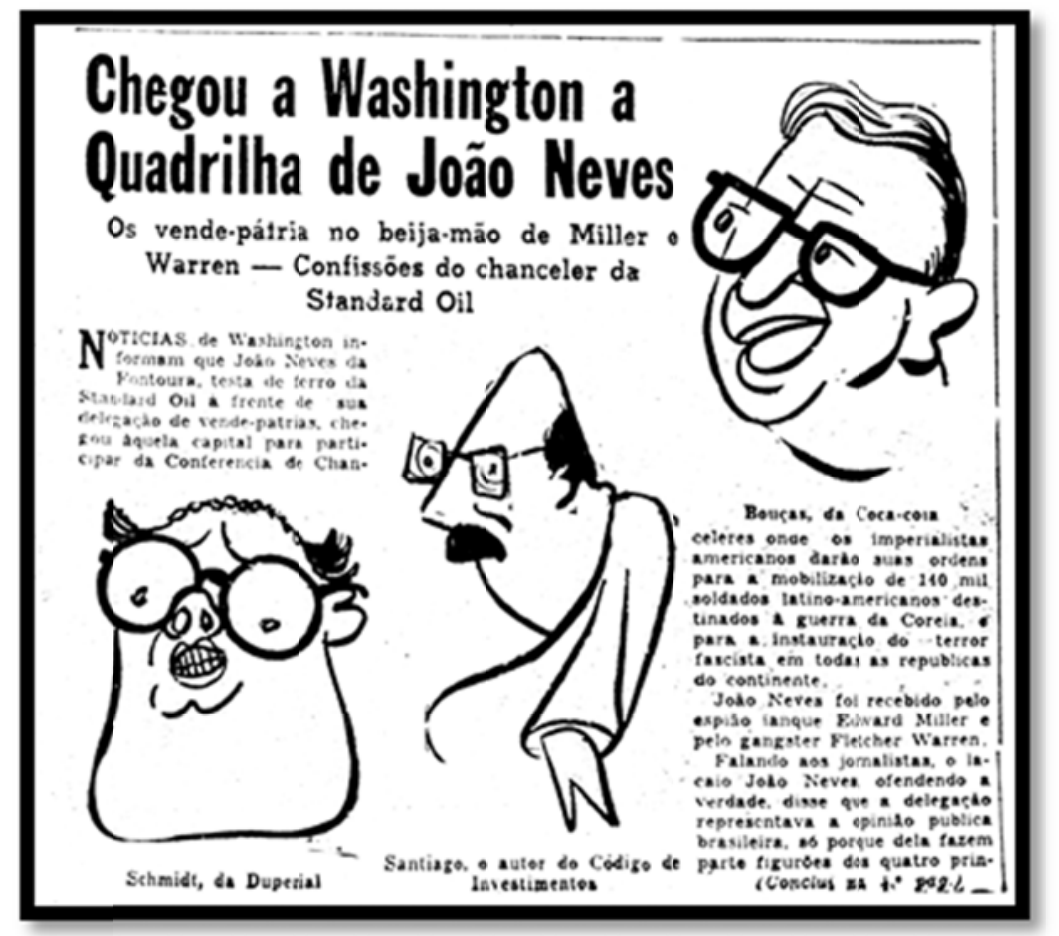

Charge 23, Imprensa Popular, 25/03/1951. P.01

Nessa notícia, podemos tomar contato com um tipo de caricatura tradicional, ou seja, realçando traços característicos físicos ridículos dos personagens, procurando somálos aos traços de caráter. Essas caricaturas ilustravam uma reportagem “denúncia', traziam o riso, eram cômicas. A relação imagem/texto é muito interessante, pois temos um texto abaixo delas identificando a "corporação" a que pertencia a figura e uma com o texto da reportagem. Se a imagem trazia o riso, o mesmo não fazia o texto. A unidade 
estaria na função de desqualificar, mas o texto não causava o riso, tinha uma linguagem dura, ofensiva.

Estas caricaturas já tinham ilustrado uma coluna chamada sugestivamente de "os vende-pátria", em que cada personagem político era analisado em suas ações públicas. Elas foram confeccionadas, provavelmente, pelo caricaturista oficial do diário "Imprensa Popular", o artista Jorge Brandão, que realizou a maioria das caricaturas no período 1951/5, sendo encontrados seus desenhos também no semanário “Voz Operária”.

No ano de 1952, os temas pela defesa do Petróleo nacional, a campanha da Paz contra o envio de tropas à guerra da Coreia e contra o Acordo Militar Brasil - USA foram correntes na imprensa comunista carioca. Em março deste ano foi assinado no Rio de Janeiro um acordo de assistência militar entre e o Brasil e os EUA, mas esse acordo, para ter valor, deveria ser aprovado pelo Congresso Nacional e, posteriormente, promulgado pelo presidente da República. Em 30 de abril, o Senado, cujo presidente era o "lacaio" Café Filho, promulgou o Acordo Militar e, em 15 de junho, foi a vez do "entreguista" Getúlio Vargas promulgar a Lei, apesar do "apelo popular” comandado pelo PCB.

Em 16 de agosto de 1952, o "Voz Operária" trouxe uma reportagem contra o Acordo. Nela encontramos seis pontos básicos, que assim podemos enumerar: “1) a imposição do comando americano às nossas forças armadas; 2 ) controle externo de nosso comércio exterior; 3) militarização da economia brasileira; 4) o Itamaraty, sucursal do departamento de Estado; 5) imposição do fascismo ianque, e 6) o governo ianque é quem decidiatudo." ("Em defesa de nossa Pátria, abaixo o 'Acordo Militar' ",Voz Operária, 16/08/1952, p.05).

Uma charge na qualse vê o uso da zoomorfia foi publicada em "Voz Operária", em agosto de 1952 (charge 24). Por ela, vemos o Tio Sam com a chave na mão, afastando os cães com "biscoitos". A chave que garantia a entrada no Brasil era o Acordo Militar, e os animais foram identificados pelas faces e por uma marca na parte traseira deles com "JN" e "G", ou seja, João Neves e Getúlio Vargas. Esses cães, que deveriam cuidar do Brasil, em troca de uns biscoitos (moedas) deixaram seus postos e não cumpriram suas funções. $O$ uso de animais serviu para desqualificar os governantes e mostrar o caráter frágil e dúbio 
de ambos. De outro lado, a nação norte-americana foi representada pelo seu símbolo maior, o Tio Sam, que aqui aparece em papel suspeito, um tanto furtivo. Esta charge resumiu bem a visão construída pelo discurso da imprensa comunista carioca em relação ao governo brasileiro e ao Acordo Militar: submissão, intervenção e controle.

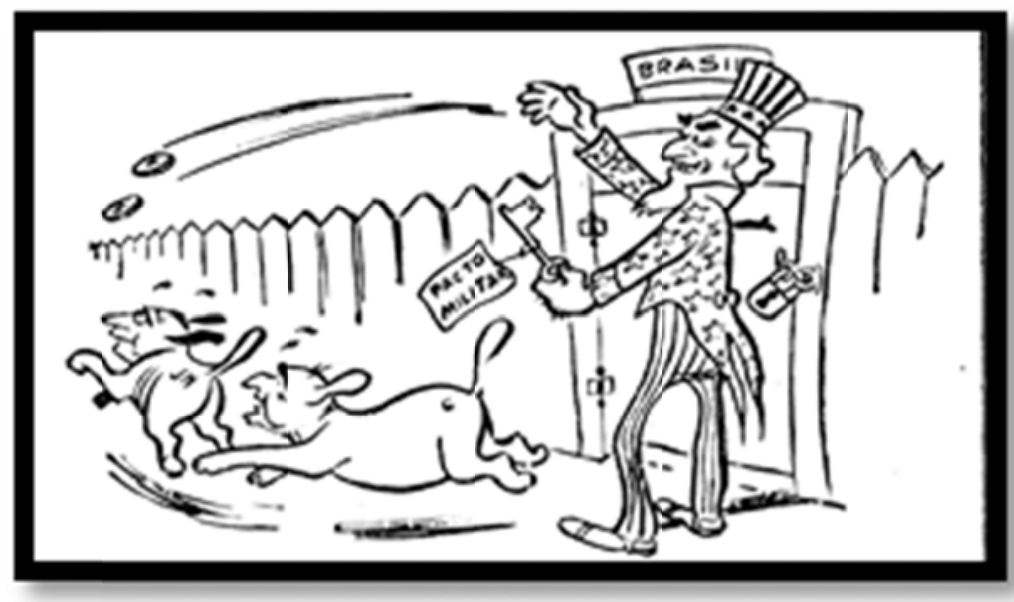

Charge 24, Voz Operária, 16/08/1952, p.05

O relógio marcava meia-noite, o Ano Novo havia chegado. Era o ano de 1953, nenhuma novidade para os leitores da imprensa comunista carioca. A charge 25 de autoria do caricaturista russo radicado nos EUA, Boris Gorelick, demonstra mais uma vez a versatilidade do artista brasileiro, ou quem sabe da redação do jornal, em adaptar uma imagem produzida fora do país para nossos costumes e linguagem.

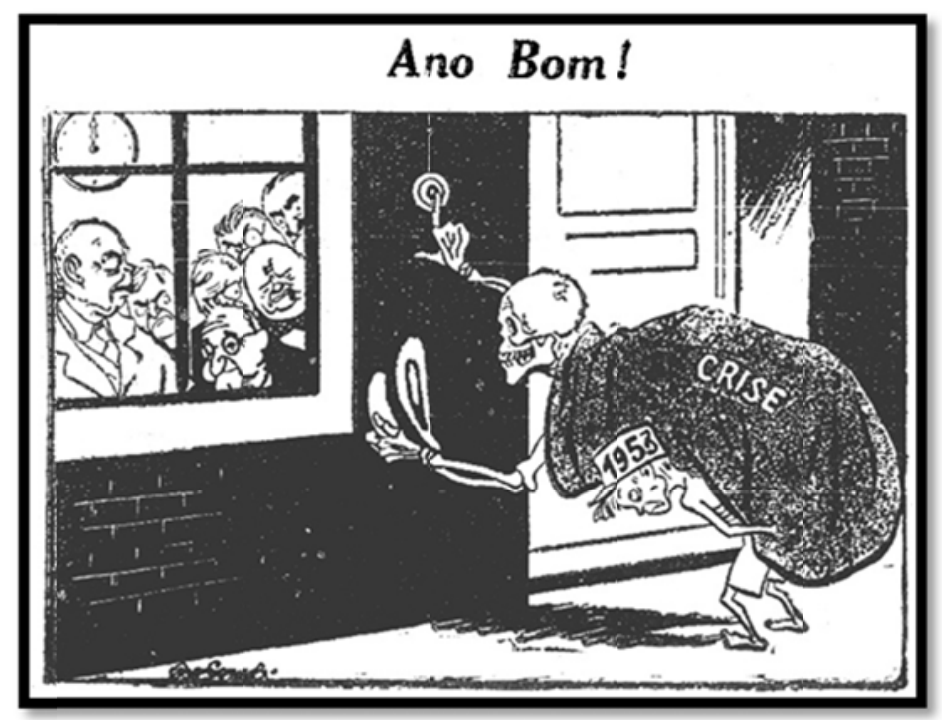

Charge 25, Voz Operária, 03/01/1953, P. 01 
“Uma troca, uma troca. Um Ano Bom por uma coisa gostosa”, diziam as crianças ao serem atendidas depois de chamarem à porta. Do dono da casa era aguardado um pedaço de bolo ou outra coisa apetitosa e a ele era desejado e por ele esperado um Ano Bom. Uma troca justa! Uma tradição perdida no tempo! Tal tradição não passou despercebida pelo "criador" da charge, pois o título da mesma foi muito sugestivo. Ao leitor de então, o título e a imagem ajudavam a formular a ideia desejada pelo "criador" da mesma. Getúlio Vargas foi colocado como um penetra na festa, incluído no meio de figuras internacionais importantes. O rosto de Vargas, bolachudo e sorridente, destoava dos demais, que eram mais carrancudos, desconfiados da surpresa que lhe batia à porta. Lá fora estava não um grupo de meninas e meninos, como era nossa tradição, mas apenas um menino solitário, magérrimo, com um boné identificando o ano (1953) e carregando um enorme saco com os dizeres em português: crise. Dentro desse saco havia um esqueleto, que, sorridente (como todas as caveiras), tocava a campainha e fazia um cumprimento com o seu chapéu. Estaria pedindo alguma coisa? Estaria entregando alguma encomenda? Seria a crise do capitalismo? Afinal, o que Getúlio estava fazendo aí? Bem, a infiltração de Vargas na festa, dando um caráter nacional ao evento, simbolizava a pouca esperança que o povo brasileiro deveria ter para o ano de 1953, já que com ele na presidência as coisas não deveriam mudar muito.

As temáticas contra o governo foram as mesmas. Vimos que o Acordo Militar só foi aprovado no meio do ano; assim, até esse período tal tema foi predominante. A perda de divisas, a carestia da vida, a "demagogia”, a entrega das riquezas nacionais e a quebra de soberania foram os demais temas apresentados com destaque pela imprensa comunista carioca.A charge 26 , publicada na página central (dupla), veio acompanhada de várias caricaturas (Vargas, Jango, José Américo, Adhemar de Barros, Amaral Peixoto, Brigadeiro Eduardo Gomes e Velasco), todos próceres de partidos políticos (PTB, UDN, PSD, PSB e PSP), que empunhavam uma bandeirinha dos EUA. O título da reportagem era “Pregão de novas 'teorias' para enganar o povo...", em quebuscou desmoralizar as teorias ("independente e esquerdista”, “evolucionismo", “nacionalismo", “moralização”) dos partidos políticos brasileiros, colocando-os como submetidos às vontades dos EUA, sem apresentar nada de novo. A charge 26 seguiu a linha de 
denúncias, apresentando Vargas como um "entreguista" das riquezas nacionais, pois abaixo da imagem estava o diálogo entre Vargas e Vicente Ráo: “pergunte-lhe o que ele quer mais..." (“Pregão de novas 'teorias' para enganar o povo...”, Voz Operária. 19/09/1953, pp. 6-7).

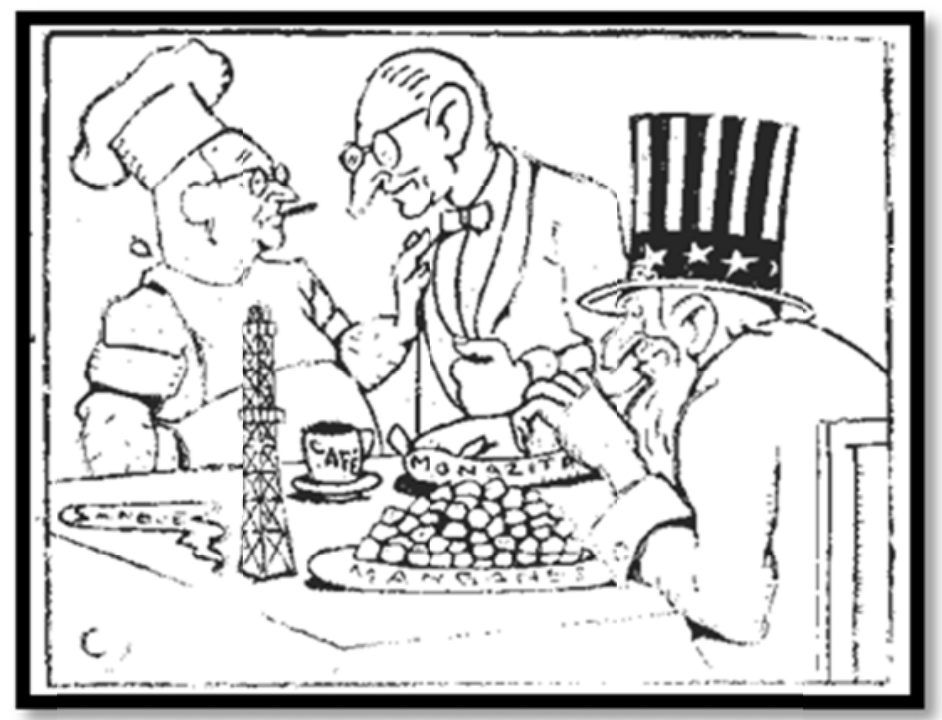

Charge 26, Voz Operária. 19/09/1953, Pp.6/7

A crise institucional pela qual passou o PCB com o relatório Kruschev trouxe à tona críticas de vários militantes ao programa do Partido e à postura do Comitê Central perante a administração Vargas. Roberto Morena, diretor do jornal comunista dirigido à classe trabalhadora "Gazeta Sindical", assim se expressou diante da atitude tomada: “Caracterizando mecanicamente o governo Vargas como um governo de latifundiários e de grandes capitalistas a serviço do imperialismo norte-americano, nós, os comunistas, fomos os auxiliares mais eficientes dos golpistas de 24 de agosto"(MORENA, Roberto “Algumas opiniões sobre o programa e a tática”, Voz Operária, 03/11/1956, pp. 06-7).

Hélio Benévolo (2003, p. 120), jornalista do “Imprensa Popular”, comentou do exagero e da falta de senso nas críticas dirigidas ao governo Vargas:

Uma conjuntura reacionária e golpista, cujo objetivo estava por demais claro. Somente nós não víamos. A fúria com que atacávamos o Governo Vargas encerrava até aspectos pitorescos, como um pichamento, na avenida Marechal Floriano- Os ianques invadiram a Guatemala, o culpado foi Vargas. 
A partir do suicídio do presidente, o PCB mudou sua orientação política, aceitando o PTB e outras "forças progressistas" como passíveis de diálogo.

\section{Aplicando conceitos, observando imagens e fazendo conclusão}

Em linhas pretéritas, estudiosos das imagens apresentaram como ficou a caricatura e a charge no período estadonovista em que, pela censura, os artistas do traço foram obrigados a fazer somente caricaturas de costumes (SILVA, 2014; COTRIM, 1965; Lima, 1963). Da mesma forma, J. Carlos expressou que fazer uma pessoa famosa com deformação não tinha significado. Partindo desta última posição, a caricatura não é, como apresentam a maioria dos estudos, "carregar" na figura desenhada, fazer um narigão, um orelhão, etc. (TEIXEIRA, 2001, p. 73). Não, pode ser até isto, mas não apenas. Da mesma forma, a caricatura não é apenas destruição, desmoralização, trazer o ridículo, inclusive propiciando o riso. Ela pode causar a repulsa, o ódio; pode trazer alegria e elogios. As possibilidades estão colocadas pelos traços do desenhista, a situação ou personagem retratado e, em especial, cumplicidade do leitor.

A caricatura de costume ou a charge de costume traz uma visão, em geral cômica, dos valores e comportamentos que ocorrem no cotidiano. Mas existem outras formas, ou outros tipos de caricaturas e charges, tais como: política, social, político-social, festiva, fantástica, pessoal, comportamental etc. (CARMONA, 2003; ABREU, 2001).

A imprensa comunista brasileira utilizou o apoio de artistas brasileiros e estrangeiros (estes via sua agência internacional de notícias) para produzir suas imagens. Como visto acima, Quirino Campofiorito, por exemplo, era um artista plástico e crítico de arte e não um caricaturista ou chargista profissional. Da mesma forma, Jorge Brandão, este um dos poucos contratados e remunerados para tal atividade. Os demais participantes eram militantes, pessoas que professavam o mesmo ideal. Assim, as imagens da imprensa comunista devem ser vistas e entendidas dentro de um embate ideológico, em especial pós-47, com o acirramento da "Guerra Fria". Seus artistas defendiam um ideal político e transformações econômicas e políticas. Assim, os símbolos usados, a carga crítica agressiva pretendida e utilizada buscava denunciar uma situação 
cumplicidade poderia causar o riso, mas este não necessariamente é a chave da proposta da imagem.

Partindo desses princípios, e ao estudarmos a imprensa comunista, verificamos que era necessária a criação de mais dois conceitos: caricatura ideológica e charge ideológica. Definimos caricatura ideológica como: imagem de personagem política, podendo abranger também fato político envolvido na questão proposta na ilustração, com a agressividade como essência. O humor não é seu objetivo final, mas pode existir de forma irônica visando denunciar o caráter do retratado. O uso do grotesco, da zoomorfia, da busca da equivalência com uso de símbolos políticos é uma de suas possibilidades. Quanto à definição de charge ideológica, podemos manter as mesmas características da caricatura, apenas nos dirigindo ao fato político em especial, destacando-se o uso de símbolos (GAWRYSZEWSKI, 2008, p. 24).

Como a função da imprensa comunista, conforme os editoriais apresentados e as falas de seus líderes, era dar a palavra orientadora de seus guias, esclarecer dúvidas, pôr fim às confusões existentes nas cabeças da classe operária (o PCB se dizia o representante desta classe), só através da leitura da imprensa comunista é que o povo poderia saber quais direções seguir, em quem votar, aprender com os grandes pensadores do marxismo, leninismo e estalinismo. Sua vasta rede, que como visto, buscava atender a todos (operários, intelectuais, mulheres etc.), devia limitar, enquadrar e conduzir as ações desses grupos: que associações fundar, que lutas encaminhar, que tipo de arte produzir e assim por diante.

Um elemento importante, que pôde ser visto nas imagens passadas, é a relação imagem-texto. Títulos, nominação dos personagens, diálogos, legendas etc. ajudam (ou dirigem) o leitor a entender a mensagem proposta pelo artista. Mas como boa parte da população era analfabeta, esse tipo de relação se tornava inócuo. 
Assim, as charges apresentadas neste texto produzidas pela imprensa comunista apresentam temáticas políticas nacionais que estavam na pauta política do PCB. Se não houve charge ou caricatura de Vargas (no "queremismo") e do presidente Dutra até 1947 foi porque eles eram vistos como aliados políticos. Quando da mudança de postura do partido comunista, as charges apareceram e com elas as denúncias e a formação de uma opinião sobre os retratados ou seus governos, no caso aqui tratado, que é Getúlio Vargas, o mesmo foi caracterizado com seu charuto, e denominado como mentiroso, criador de miséria, fundador de um partido político de ricos, causador dos males do cotidiano do povo (inflação, falta de moradia, comida, transporte de qualidade etc.), vendilhão da pátria, aliado dos EUA e da guerra, entre outros. Os temas são nacionais e internacionais. Os traços, aqueles que não eram de profissionais, não possuíam muita qualidade, o que poderia prejudicar a atração do olhar do leitor e, da mesma forma, dificultar a mensagem proposta e o riso.

“Careta”, uma revista comercial, como visto, possuía profissionais qualificados e com anos de produção e experiência, até mesmo dentro da revista, já que foi longeva. Era rodada na gráfica de seu proprietário, e a mesma era de qualidade, possibilitando o uso de cores (limitadas, é claro). J. Carlos, um de seus desenhistas, era reconhecido nacional e internacionalmente por seus traços delicados, alegres e diretos, com uma capacidade de crítica ácida e cômica ao mesmo tempo, como poucos. Outro desenhista que compunha o quadro de contratados de "Careta”foi Théo, que substituiu J.Carlos na confecção das capas quando ele faleceu (outubro de 1950). Por fim, Luis Carlos, chargista, veio ocupar a parte interna junto com Théo. Todos possuíam traços agradáveis que atraíam a visão do leitor.

Com uma história já longa de 37 anos, quando do início do período deste estudo (1945), "Careta" foi um baluarte da defesa da democracia no fim do "Estado Novo" e na queda do ditador Getúlio Vargas, em 1945. Portanto, assim que pôde se ver livre da censura do DIP, voltou a publicar charges de Vargas. Este foi desenhado como mentiroso, golpista, semideus, aliado de açambarcadores e bicheiros, criador de um partido político de milionários, adorador do puxa-saquismo, criador das dificuldades do povo (inflação, 
dívida externa, câmbio negro, filas etc.), usurpador da máquina estatal em proveito próprio ou de aliados e familiares, entre outros.

Pode-se, portanto, verificar nas linhas acima semelhanças na visão de quem foi Vargas para "Careta" e as publicações do PCB. Mas, também, a análise das imagens nos permite verificar as diferenças nas abordagens dos temas e nas formas do descaramento e da denúncia. Visto um aspecto essencial do profissionalismo dos desenhistas da "Careta" frente ao amadorismo ou o caráter de engajamento e "doação" à causa dos desenhistas comunistas, nos é dado destacar uma diferença substancial. Ao militante do PCB não é dada liberdade da criação, na medida em que cabia ao jornal "orientar" o leitor para a compreensão da situação política, econômica, social e sindical vigente. Em tese, tal fato não ocorria com o contratado de "Careta", mas os desenhos apresentados mostraram uma conexão entre o editorial da revista e as mensagens enviadas pelas charges.

Considerando o conceito de charge e/ou caricatura ideológica; a diversidade criada para definir o conceito de charge e/ou caricatura política; a existência ou não do riso; de estar voltada para a questão política vivida pela população; de ter uma sobrevida no tempo visto a permanência do personagem ou da situação e de estar voltada em desmascarar ou retratar o retratado etc., pergunta-se: como se encaixariam as imagens vistas de "Careta"? A resposta seria que elas foram concebidas como políticas, e não de forma ideológica. O veículo jornalístico, o público leitor, o engajamento político do artista, entre outras questões, nos indicam como e onde localizar o periódico estudado. Assim, há uma diferenciação clara entre as publicações aqui referenciadas.

E como se dá isso nas charges? Já foram discutidas algumas diferenças nos traços; aprofundemo-las. Se compararmos a charge de "Careta" (charge 5) em quedois cidadãos comuns estão em seu diálogo denunciando a inoperância de Vargas como senador, e a charge de Quirino (charge 16), que mostrava Getúlio Vargas com a boca selada ("boca de siri"), podemos tirar algumas conclusões. Primeiro, o papel fundamental da escrita, pois sem ela a primeira seria sem sentido, visto que a figura de Vargas só aparece no diálogo, e a segunda daria margem a interpretações equivocadas, já que Vargas poderia estar impedido de falar, ou seja, seria uma vítima. Os traços seriam uma segunda diferença: na 
"Careta”, as figuras são caricatas, e na segunda é o próprio Vargas (sem graça). E por fim, voltando à escrita, a denúncia do diálogo de "Careta" causa o riso, pois o outro personagem respondeu à questão de forma irônica e precisa. No desenho comunista, o texto, embora popular, não busca o riso.

Outra diferença apresentada no presente texto é a discussão do "Queremismo", totalmente ausente das publicações comunistas e desmoralizante e debochada em "Careta". Tanto o movimento dito "popular" quanto a denúncia da situação da econômica e social apresentados nas charges de "Careta" causavam o riso, desqualificavam a permanência de Vargas, causador dos problemas cotidianos e "cego" para eles (charge 2).

Quanto à guerra da Coreia, foi um tema caro para os comunistas, que publicaram em sua imprensa vários artigos condenando os EUA e seus aliados e diversos desenhos denunciando as mortes de populares e os heroísmos da resistência da esquerda coreana. A revista "Careta" (charge 13), conforme apresentado, dispôs de apenas um desenho e, neste, denunciava o caráter financeiro e não ideológico de Vargas ao aderir aos EUA na guerra da Coreia na busca de divisas: mandar soldados em troca de dinheiro. Com traços leves, apresenta Vargas, elegante e com seu charuto, conversando com o ministro da Guerra, este devidamente fardado e com ar tranquilo. No caso da imprensa comunista, Vargas (charge 20), junto com outros de seu governo, está envolto em uma lista popular contra o Pacto Militar. Ao fundo, o presidente americano e outros com um saco de dinheiro (divisas ou suborno?). Mesmo para o militante, a charge não causa o riso, apenas uma satisfação. Sem dúvida um belo desenho de Jorge Brandão, denunciador de uma política guerreira.

Politicamente contrárias ao político Vargas, as publicações aqui estudadas buscaram denunciar e desqualificar sua figura. Neste sentido, em todas as eleições ocorridas, "Careta" apoiou Brigadeiro Eduardo Gomes e desqualificou os demais candidatos e partidos políticos. Já o PCB teve seus candidatos próprios ou se eximiu de participar das eleições (1950), mas sempre com uma imprensa crítica aos partidos existentes. No caso do PTB, todos se posicionaram em descrevê-lo como um partido de milionários. "Careta" denunciou que os "novos ricos", ricos graças às negociatas com 
charge de Quirino (charge 18), na "Tribuna Popular”, trouxe as figuras que compunham o PTB com seus cargos e com seus nomes, respectivamente. Figuras bem trajadas, devidamente nomeadas. Traços simples cujo conjunto não trazia o riso como essência.

As mesmas linhas de construção de imagem se verificam com o tema do petróleo. Colocadas em pontos antagônicos (o PCB foi um dos líderes do movimento do "petróleo é nosso!"), também as imagens trazem fórmulas diversas de abordagem. Para "Careta" bastou, para se posicionar contra, colocar uma garrafa de água mineral ao lado da garrafa de petróleo e perguntar: "Teremos petróleo pelo preço de água mineral?" (charge 15). Para o PCB, a imagem extrapolou a questão do óleo negro (charge 26), pois desejava denunciar Vargas como um traidor da pátria, um vendilhão, ao entregar o café, o manganês, a areia monazítica, o petróleo e o sangue do brasileiro ao Tio Sam.

Uma questão que chama a atenção é a representação dos eleitores de Vargas. De forma cômica e descarada, "Careta" listou estes e as razões do voto (charge 8). Ao PCB não era permitido pensar o eleitor a não ser como um trabalhador a ser conduzido pelo saber dos guias. O trabalhador urbano (o irmão mais velho do camponês), devidamente vestido com seu macacão, enfrentou Vargas pelo aumento salarial (charge 20). Mas o eleitor, o povo, foi sim representado, mas com seus problemas, como doença, fome e o analfabetismo... (charge 22). Para concluir, já que muito ainda se poderia comentar, a forma de denunciar a demagogia de Vargas foi uma constante nas publicações citadas. Entretanto, mais uma vez, se para a "Careta" a solução se dava de forma cômica e com desenhos atrativos ao seu público, para a imprensa comunista o tom ideológico e de "orientação" ao seu leitor foi a chave. Depois da chuva de votos, o "Prometeu" Vargas dava a solução para a crise: o povo trabalhar mais. Se necessitavam de empréstimos para pagar empréstimos aos americanos, caberia ao Jeca trabalhar para pagar a conta (charge 14). 


\section{Referências}

ABDELMALACK, Genny. Momentos da história do Brasil através da caricatura (1900/37). 1991. Dissertação (Mestrado em Artes) -Universidade de São Paulo, Departamento de Comunicações e Artes, São Paulo, 1991

ABREU, Carlos. Hacia una definición de caricatura. Revista Latina de Comunicación Social, n.40, abr.2001. Disponível em: <http://www.ull.es/publicaciones/latina/ 2001/latina40abr/102cabreuvii.htm>. Acesso em: 26 de julho de 2016.

ALBERTI, Verena. O riso e o risível. Rio de Janeiro: Zahar, 1999.

BENÉVOLO, Hélio. Relembranças. Rio de Janeiro: Edição, 2003.

CAMPOS, Maria de Fátima Hanaque. Rian: a primeira caricaturista brasileira (1a. fase artística - 1909/26). 1990. Dissertação (Mestrado em História da Arte) - USP - ECA, São Paulo, 1990.

CARMONA, Rubén Dário Acevedo. Política y caudillos colombianos em la caricatura editorial (1920-1950) http://www.hors-limites.fr/edition/2017/petit-pays/25-03-2017-19-00/. 2003. Tese (Programa de Doctorado em Historia) - Universidad de Huelva, Espanha, 2003.

CARETA, Rio de Janeiro, 1945-1954

CARONE, Edgard. O PCB (1943-1964), Vol. II, São Paulo: Difel, l982.

CARONE, Edgard. Movimento operário no Brasil (1945-I964). São Paulo: Difel, Volume II, 1981.

COSTA, Wagner Cabral da. Pra rebecca, o rebeco e a rabeca: sátira e caricatura de Vargas na revista Careta (1946-50), In: ENCONTRO NACIONAL DE ESTUDOS DA IMAGEM, Londrina. 2011. Anais... Londrina: UEL, maio de 2011.

COTRIM, Álvaro. O Rio na caricatura. Rio de Janeiro: Biblioteca Nacional, 1965.

CLASSE OPERÁRIA, Rio de Janeiro, 1951-54

FALCÃO, João. O Partido Comunista que eu conhecia (20 anos de clandestinidade), Rio de Janeiro: Civilização Brasileira, 1988.

FLORES, Elio Chaves. Representações cômicas da República no contexto do Getulismo. Revista Brasileira de História, São Paulo, v.21, n.40, p.133-157, 2001.

FONSECA, JOAQUIM.da.Caricatura: a imagem gráfica do humor. Porto Alegre: Artes e Ofícios, 1999. 
FUNDAMENTOS, São Paulo, 194 9-1954

GARCIA, Sheila Nascimento. Revista Careta: um estudo sobre humor visual no Estado Novo (1930-1945). 2005. Dissertação (Mestrado em História) - UNESP - Faculdade de Ciências e Letras , Assis, -2005

GAWRYSZEWSKI, Alberto. Arte visual comunista. Londrina: LEDI/UEL, 2009.

GAWRYSZEWSKI, Alberto. Conceito de caricatura: não tem graça nenhuma. Domínios da Imagem, Londrina: LEDI/UEL, Ano I, n. 2, pp. 7-26, Maio 2008. Disponível em <http://www.uel.br/revistas/uel/index.php/dominiosdaimagem/article/view/19302>. Acesso em: 27 DE JULHO DE 2016

GAZETA SINDICAL, Rio de Janeiro, 1948-50

IMPRENSA POPULAR, Rio de Janeiro, 195l-54

LIMA, Herman. História da caricatura no Brasil. Rio de Janeiro: José Olímpio, 1963. Volume 01

LONER, Beatriz. O PCB e o manifesto de Agosto. 1985. Dissertação (Mestrado em História) - UNICAMP, Campinas, 1985 .

MOTTA, Rodrigo Patto Sá. Em guarda contra o perigo vermelho (1917-1964), São Paulo: Perspectiva: FAPESP, 2002 (Estudos;180).

MOTTA, Rodrigo Patto Sá. Em guarda contra o perigo vermelho: o anticomunismo no Brasil, 1917-1964. São Paulo: Editora Perspectiva, 2002

MOMENTO FEMININO, Rio de Janeiro, 1947-54

PRESTES, Luiz Carlos. Problemas atuais da democracia, Rio de Janeiro: Ed. Vitória, l948.

RIANI, Camilo. Tá rindo do quê? (Um mergulho nos salões de humor de Piracicaba), Piracicaba: UNIMEP, 2002.

RUBIM, Antônio Albino Canelas. PC: cultura e política cultural. 1986 Tese (Doutoramento em Ciências Sociais)- USP - FFLCH, São Paulo, 1986.

SGARBI, Octávio. Introdução à história da caricatura brasileira. In: ANUÁRIO da Imprensa Brasileira. Rio de Janeiro: DIP, 1942.

SILVA, Marcelo Almeida. O Reich e o stato aos pés do cristo: o totalitarismo sob a ótica das charges da revista careta durante a segunda grande guerra. 2014. Dissertação (Mestrado em Historia) -UFJF, Instituto de Ciências Humana, Juiz de Fora/MG, 2014 . 
SILVA, Marcos. Prazer e poder do amigo da onça, 1943-1962. Rio de Janeiro: Paz e Terra, $1989.305 \mathrm{p}$

TAVARES, Rodrigo Rodriguez. Desenhando a revolução: a luta de imagens na imprensa comunista (1945-1964). 2010. Tese (Doutorado em História Social) - Faculdade de Filosofia, Letras e Ciências Humanas, São Paulo, 2010.

TEIXEIRA, Luiz G. S. O traço como texto: a história da charge no Rio de Janeiro de 1860 a 1930, Rio de Janeiro: Fundação Casa de Rui Barbosa, 2001.

TORRES, Juliana. A representação visual da mulher na imprensa comunista. 2009.

Dissertação ( Mestrado em História) - Universidade Estadual de Londrina, Programa de História Social, Londrina, 2009.

TRIBUNA POPULAR, Rio de Janeiro, 1945-47.

VOZ OPERÁRIA (ÓRGÃO OFICIAL DO PCB), Rio de Janeiro, 1949-54.

Recebido em 06/09/2016 Aprovado em 17/02/2017 